GARDNER ET AL., PHYLOGENOMICS AND GENERIC REVISION OF MOREAE

\title{
1 Repeated parallel losses of inflexed stamens in Moraceae: phylogenomics and generic revision of the tribe Moreae and the reinstatement of the tribe Olmedieae (Moraceae)
}

4 Elliot M. Gardner1,2,3,*, Mira Garner1,4, Robyn Cowan5, Steven Dodsworth5,6, Niroshini

5 Epitawalage5, Deby Arifiani7, S. Sahromis, William J. Baker5, Felix Forest5, Olivier

6 Maurin5, Nyree J.C. Zerega9,10, Alexandre Monro5, and Andrew L. Hipp1,11

81 The Morton Arboretum, 4100 IL-53, Lisle, Illinois 60532, USA

92 Case Western Reserve University, Department of Biology, 2080 Adelbert Road,

10 Cleveland, Ohio 44106, USA (current affiliation)

113 Singapore Botanic Gardens, National Parks Board, 1 Cluny Road, 259569, Singapore

12 (current affiliation)

134 University of British Columbia, Faculty of Forestry, 2424 Main Mall, Vancouver, British

14 Columbia, V6T 1Z4, Canada (current affiliation)

155 Royal Botanic Gardens, Kew, Richmond, TW9 3AE, United Kingdom

16 6 School of Life Sciences, University of Bedfordshire, Luton LU1 3JU, United Kingdom

17 (current affiliation)

187 Herbarium Bogoriense, Research Center for Biology, Indonesian Institute of Sciences,

19 Cibinong, Jawa Barat, Indonesia

208 Center for Plant Conservation Botanic Gardens, Indonesian Institute of Sciences, Bogor,

21 Jawa Barat, Indonesia

229 Chicago Botanic Garden, Plant Science and Conservation, 1000 Lake Cook Road,

23 Glencoe, IL, 60022, USA

2410 Northwestern University, Plant Biology and Conservation Program, 2205 Tech Dr.,

25 Evanston, IL, 60208, USA

2611 The Field Museum, 1400 S Lake Shore Dr., Chicago, IL 60605, USA

27 a For correspondence, email elliot.gardner@case.edu

\section{Abstract}


GARDNER ET AL., PHYLOGENOMICS AND GENERIC REVISION OF MOREAE

31 We present a densely-sampled phylogenomic study of the mulberry tribe (Moreae,

32 Moraceae), an economically important clade with a global distribution, revealing multiple

33 losses of inflexed stamens, a character traditionally used to circumscribe Moreae. Inflexed

34 stamens facilitate ballistic pollen release and are associated with wind pollination, and the

35 results presented here suggest that losses of this character state may have evolved

36 repeatedly in Moraceae. Neither Moreae nor several of its major genera (Morus, Streblus,

37 Trophis) were found to be monophyletic. A revised system for a monophyletic Moreae is

38 presented, including the reinstatement of the genera Ampalis, Maillardia, Taxotrophis, and

39 Paratrophis, and the recognition of the new genus Afromorus, based on Morus subgenus

40 Afromorus. Pseudostreblus is reinstated and transferred to the Parartocarpeae, and

41 Sloetiopsis is reinstated and transferred to the Dorstenieae. The tribe Olmediae is reinstated,

42 replacing the Castilleae, owing to the reinstatement of the type genus Olmedia, and its

43 exclusion from Moreae. Streblus s.s. is excluded from Moreae and transferred to the

44 Olmediae, which is characterized primarily by involucrate inflorescences without regard to stamen position. Eight new combinations are made.

Keywords: Moraceae, mulberry family; Moreae, Olmedieae, Castilleae, Parartocarpeae, Afromorus, Ampalis, Bagassa, Maillardia, Milicia, Morus, Olmedia; Pachytrophe,

\section{Introduction}

The preservation of plesiomorphic (ancestral) characters can result in species that are similar in appearance but distantly related, connected only by a remote common ancestor. The mulberry family (Moraceae Gaudich., seven tribes, ca. 39 genera and 1,200 species) illustrates this principle well. Inflexed stamens in bud-an adaptation to wind pollination that allows explosive pollen dispersal when flowers open-were traditionally used to define a tribe of the family, the Moreae (mulberries and their allies). Yet phylogenetic analyses have revealed that inflexed stamens, an ancestral feature of both

60 Moraceae and their sister family_Urticaceae (nettles), have been lost repeatedly (Clement \& 
GARDNER ET AL., PHYLOGENOMICS AND GENERIC REVISION OF MOREAE

61 Weiblen, 2009). Thus, for example, Cecropiaceae C.C. Berg, traditionally distinguished

62 from the nettle family by the absence of inflexed stamens, is in fact embedded within the

63 Urticaceae Juss. (Berg, 1978; Clement \& Weiblen, 2009). Likewise, while mulberries

64 (Morus L.), paper mulberries (Broussonetia L'Hér. ex Vent.), and osage oranges (Maclura

65 Nutt.) were once treated as tribe Moreae Gaudich. on account of their inflexed stamens,

66 phylogenetic analyses reveal them to belong to three distinct clades, each containing an

67 assemblage of genera with and without inflexed stamens (Clement \& Weiblen, 2009;

68 Zerega \& Gardner, 2019).

This study focuses on the tribe Moreae, a clade of six genera and an estimated 66 species (Clement \& Weiblen, 2009). This widespread group of plants contains species of ecological and cultural importance, as well as the economically important white mulberry (Morus alba L.), whose leaves sustain Bombyx mori L. (Bombycidae), the invertebrate

73 proletariat of the silk industry.

Morphological basis for higher classification in Moraceae

By the end of the nineteenth century, Engler (1889) had circumscribed a Moraceae that is quite similar to the modern concept of the family, with two subfamilies: the Moroideae, comprising tribes Dorstenieae Gaudich., Broussonetieae Gaudich., Fatouae Engler, Moreae, and Strebleae Bureau, characterized by stamens inflexed in bud (broadly construed, including Dorstenia where they straighten gradually rather than spring outward suddenly); and the Artocarpoideae, composed of tribes Brosimae Trécul, Euartocarpeae Trécul, Ficeae Dumort., and Olmedieae Trécul and characterized by stamens straight in

83 bud. The two most influential scholars of Moraceae classification in the 20th century were

84 E.J.H. Corner and C.C. Berg. Corner considered inflorescence architecture to be the most

85 important character for higher-rank taxonomy within the family and inflexed stamens

86 consequently of secondary importance(Corner, 1962). Berg by contrast questioned the

87 utility of inflorescence architecture and took into account a variety of characters, especially

88 the presence of inflexed stamens (Berg, 1977b, 2001).

The taxonomic history of the family has leaned heavily on this stamen character.

90 Engler's Moreae (1899), unchanged in substance from Bureau's (1873), contained six 
GARDNER ET AL., PHYLOGENOMICS AND GENERIC REVISION OF MOREAE

91 genera, Ampalis Bojer, Pachytrophe Bureau, Paratrophis Blume, Pseudomorus Bureau,

92 and Morus, all with inflexed stamens that spring out suddenly at anthesis (Table 1).

93 Corner's expanded Moreae consisted of seven genera with either straight or inflexed

94 stamens, but with pistillate inflorescences never condensed into a head: Fatoua Gaudich,

95 Morus, Sorocea A. St.-Hil. (apparently including Paraclarisia Ducke), Clarisia Ruiz \&

96 Pav., Ampalis, Pachytrophe, and Streblus Lour. (including Bleekrodea Blume, Paratrophis,

97 Pseudomorus, Taxotrophis Blume, Sloetiopsis Engl. and Neosloetiopsis Engl.). Corner

98 himself, however, found the diversity of his Moreae unsatisfactory, noting that "[ $\mathrm{t}]$ oo many

99 genera on insufficient and invalid grounds trouble this small tribe" (Corner, 1962). Perhaps

100 in response, Berg's Moreae comprised all of the genera with inflexed stamens and none

101 without, including Broussonetia and Maclura but excluding Sorocea and Clarisia,

102 providing a simple character with which to delimit the tribe(Berg, 2001; Berg \& al., 2006).

103 Recent phylogenetic work has supported a third approach, with the Moreae

104 comprising six genera, including genera with both straight (Sorocea, Bagassa Aubl.) and

105 inflexed (Broussonetia, Maclura) stamens (Clement \& Weiblen, 2009). These studies also

106 suggest that the character state of inflexed stamens is plesiomorphic and is the ancestral

107 state for both Moraceae and Urticaceae (Datwyler \& Weiblen, 2004; Zerega \& al., 2005;

108 Clement \& Weiblen, 2009). Inflexed stamens, which are precursors to ballistic pollen

109 release, are associated with wind pollination (Bawa \& Crisp, 1980; Berg, 2001), while the

110 loss of inflexed stamens is associated with animal pollination. Although dominant in the

111 Moreae, inflexed stamens also occur in two other tribes: Maclureae W.L. Clement \& G.

112 Weiblen and Dorstenieae. Genera lacking inflexed stamens occur in all seven tribes of

113 Moraceae (Clement \& Weiblen, 2009; Zerega \& Gardner, 2019).

115 Taxonomic summary of Moreae

116 Following Clement \& Weiblen (2009), the Moreae comprise six genera and an

117 estimated 66 species: Bagassa (1), Milicia Sim (2), Morus (16), Sorocea (16), Streblus

118 (23), and Trophis P. Browne. (8) (Berg, 1977a, 2001; Berg \& al., 2006; Clement \&

119 Weiblen, 2009; Filho \& al., 2009; Machado \& al., 2013; Santos \& Neto, 2015). Here, we

120 present an overview of these genera. 
GARDNER ET AL., PHYLOGENOMICS AND GENERIC REVISION OF MOREAE

Morus L., the true mulberries, is characterized by leaves with crenate margins and

122 trinerved bases, stamens inflexed in bud, and many-flowered pistillate spikes whose four-

123 parted perianths become fleshy in fruit, the aggregations superficially resembling a

124 blackberry. Morus comprises approximately 16 species whose delimitation requires further

125 research. There are three subgenera: Morus (ca. 14 species) which is found in temperate to

126 tropical Asia and from North America to Mexico; Gomphomorus Leroy, a single species

127 restricted to tropical South America; and Afromorus (Bureau ex Leroy), a single species

128 restricted to tropical Africa. Previous phylogenetic work has suggested that these three

129 subgenera may not form a monophyletic clade (Nepal, 2012). Milicia (2 spp., Africa) has

130 inflorescences which somewhat resemble those of Morus, but the leaves of Milicia, with

131 entire margins and pinnate venation, prevent any confusion of the two genera.

132 Streblus Lour., with 23 species from India to Southeast Asia and Oceania, is

133 morphologically heterogeneous, but its species are all characterized by stamens inflexed in

134 bud and pistillate flowers with more or less free tepals that enclose the fruit loosely or not

135 at all. Initially described by Loureiro based on the widespread S. asper Lour.- - notable for

136 its discoid-capitate staminate inflorescences with the rudiments of an involucre-Streblus

137 was broadened by Corner (1962), bringing in as sections Taxotrophis, Phyllochlamys

138 Bureau, Paratrophis (including Pseudomorus), Pseudostreblus Bureau, Bleekrodea, and

139 Sloetia Teijsm. \& Binn. (apparently including Sloetiopsis but without making any

140 combinations). None of these have discoid-capitate inflorescences; they mostly have

141 spicate staminate inflorescences, and the latter two can have bisexual inflorescences.

142 Corner viewed these sections as fragments of an ancient lineage preserving ancestral

143 characters (Corner, 1975). Following additional work by Corner (1970, 1975), Berg

144 included the genera Ampalis and Pachytrophe as section Ampalis (Bojer) C.C. Berg,

145 subsumed Sloetiopsis and section Taxotrophis into section Streblus, and excluded section

146 Bleekrodea, reinstating it as a genus (Berg, 1988). Berg later reinstated section Taxotrophis,

147 whose species are unique in bearing axillary spines (Berg, 2005; Berg \& al., 2006). In

148 2009, Clement and Weiblen reinstated Sloetia at generic rank and transferred it and

149 Bleekrodea to Dorstenieae based on phylogenetic evidence (Clement \& Weiblen, 2009). 
GARDNER ET AL., PHYLOGENOMICS AND GENERIC REVISION OF MOREAE

Trophis $\mathrm{P}$. Browne is characterized by stamens inflexed in bud, spicate staminate inflorescences, and tubular pistillate perianths, becoming fleshy and enclosing the fruit, except for the monotypic section Olmedia (Ruiz \& Pav.) C.C. Berg (T. caucana), which has discoid-capitate staminate inflorescences with an involucre. Trophis (regrettably conserved over Linnaeus's Bucephalon L.) as recognized by Berg $(1988,2001)$ had five sections: Trophis, restricted to Latin America; Calpidochlamys (Diels) Corner (previously included in Paratrophis and Uromorus), restricted to Southeast Asia (Corner, 1962); Maillardia (Frapp. ex Duch.) C.C. Berg, restricted to Africa; Malaisia (Blanco) C.C. Berg, restricted to Southeast Asia; and Olmedia, restricted to Latin America. The sinking of Olmedia into Trophis by Berg (1988), requiring the re-typification of the tribe Olmedieae Trécul, which became Castilleae C.C. Berg. Recently, Malaisia Blanco was reinstated as a genus and transferred to Dorstenieae based on phylogenetic evidence (Clement \& Weiblen, 2009), reducing the current number of sections to four.

Two Neotropical genera included in Moreae by Clement and Weiblen (2009) but not by Berg (2001) have straight stamens. While the monotypic Bagassa Aubl., with its long staminate catkins, is wind pollinated (Bawa \& Crisp, 1980), evidence suggests that Sorocea A. St.-Hil. (19 spp.), which produces racemose staminate inflorescences that do not have as many flowers as those of Bagassa, likely contains both wind- and insectpollinated species (Zapata \& Arroyo, 1978; Bawa \& al., 1985; Lewis, 1986). The pistillate perianths are subtended by pluricellular hairs, believed to serve as a substrate for a fungus which, in turn attracts pollinators (Berg, 2001). The staminate flowers of Sorocea affinis Helmsl. are apparently fragrant (fide $S$. Zona 778, 21 Nov. 1997, FTBG ${ }^{\wedge}$ ) ), suggesting insect pollination for that species. If insect pollination is confirmed in Sorocea, it would likely represent another transition from ancestral wind to derived insect pollination in Moraceae.

Disagreement between the two principal recent monographers of the Moraceae, Corner (1962) and Berg (2001, 2005, 2006), over the delimitation of the Moreae has been compounded by a series of phylogenies based on the analysis of molecular (DNA sequence) data that have redefined genera and their relationships. This has resulted in a poorly delimited tribe, both with respect to diagnostic morphological characters, the genera 
GARDNER ET AL., PHYLOGENOMICS AND GENERIC REVISION OF MOREAE

180 it comprises, and the rank of several taxa (see above). Ensuring that the tribe and its genera

181 are monophyletic will result in a classification that better reflects evolutionary history,

182 providing a framework for answering broader scientific questions. Our aim, therefore, was

183 to generate a comprehensive phylogeny of the Moreae (Fig. 1) and its near allies by

184 sampling all of the potential genera and species in the tribe sensu Berg, and sensu Clement

$185 \&$ Weiblen (2009) and use this to redelimit the tribe and its genera. We aimed to do so

186 through increased taxon and genome sampling compared to previous studies, including a

187 nearly comprehensive sample of the taxa in Moreae (56/66 species) and the allied tribes

188 Artocarpeae (76/83 taxa) and Maclureae (12/12). Our data set combines phylogenomic data

189 generated using two largely non-overlapping sets of enrichment baits, one developed

190 specifically for the Moraceae (Gardner et al., 2016), the other for the whole of the

191 Angiosperms (Johnson \& al., 2019), allowing us to explore the possibilities and challenges

192 of combining samples based on largely non-overlapping loci. The resulting generic revision

193 lays the groundwork for species-level revisionary work and provides clarity to this

194 economically important clade.

195 We also set out to reconstruct the evolutionary history of inflexed stamens within

196 Moraceae using ancestral state reconstruction. The loss of inflexed stamens in

197 Castilleae+Ficeae and Artocarpeae have been associated with transitions from wind to

198 animal pollination (Momose \& al., 1998; Sakai \& al., 2000; Datwyler \& Weiblen, 2004;

199 Gardner \& al., 2018). A more complete picture of evolutionary transitions between inflexed

200 and straight stamens may help focus further research on transitions in pollination biology

201 with Moraceae.

202

203 Materials and Methods

204 We used target enrichment sequencing (HybSeq) (Weitemier \& al., 2014) to capture

205333 genes previously developed for phylogenetic work in Moraceae (the "Moraceae333")

206 (Gardner \& al., 2016; Johnson \& al., 2016). This method allows for efficient capture of

207 hundreds of loci and is suitable for both fresh material and degraded DNA from herbarium

208 material (Villaverde \& al., 2018; Brewer \& al., 2019), which comprises much of the

209 material employed in this study. 
GARDNER ET AL., PHYLOGENOMICS AND GENERIC REVISION OF MOREAE

Taxon sampling, library preparation, and sequencing

212 We sampled 56 out of 66 species (and all genera) in Moreae as well as select outgroup

213 taxa from Artocarpeae using DNA from leaf tissue preserved on silica gel or - in most

214 cases - samples from herbarium specimens (Table S1). In either case, DNA was extracted

215 using a modified CTAB method, usually with increased incubation times to maximize yield

216 from herbarium tissue(Doyle \& Doyle, 1987; Hale \& al., 2020). Samples were quantified

217 using a Qubit fluorometer (Invitrogen, Life Technologies, California, USA), and herbarium

218 samples were run on a gel to test for degradation. For most samples $200 \mathrm{ng}$ of DNA was

219 used for library preparation; for some low-yield samples, as little as $50 \mathrm{ng}$ was used, and for

220 very degraded samples, as much input as possible was used, up to $400 \mathrm{ng}$. Undegraded

221 DNA was fragmented either using NEB DNA Fragmentase (New England Biolabs,

222 Ipswich, Massachusetts, USA) or on a Covaris M220 (Covaris, Wobum, Massachusetts,

223 USA). DNA samples with an average fragment size less than $500 \mathrm{bp}$ were not fragmented

224 at all, and partially-degraded samples with an average fragment size of over 500 bp were

225 fragmented on the Covaris M220. TruSeq-style library preparation was carried out using

226 either the KAPA Hyper Prep kit (Kapa Biosystems, Wilmington, MA) or the NEB DNA

227 Ultra 2 kit following the manufacturer's protocols, except that end repair, A-tailing, and

228 adapter ligation were carried out in reduced-volume reactions $(0.25 \mathrm{x}$ for KAPA and $0.5 \mathrm{x}$

229 for NEB) to reduce costs. Final products were quantified on the Qubit and combined in

230 equal molecular weights into pools of 16-20 samples. The pools totaled $1,200 \mu \mathrm{g}$ each if

231 enough library preparation was available. Pools were hybridized for 16-24 hours to custom

232 Moraceae probes (Gardner et al, 2016) using a MYBaits kit (Arbor Biosciences, Ann

233 Arbor, Michigan, USA) following the manufacturer's protocol, except that the probes were

234 diluted 1:1 with nuclease-free water. Hybridization products were reamplified using KAPA

235 Hot Start PCR reagents following the MYbaits protocol, quantified on the Qubit, and

236 quality-checked on an Agilent BioAnalyzer (Agilent Technologies, Palo Alto, California,

237 USA). Samples with adapter dimer peaks were cleaned using 0.7x SPRI beads and re-run

238 on the Qubit and BioAnalyzer. An initial sequencing run took place on a MiSeq 2 x 300bp

239 run (v3) (Illumina, San Diego, California, USA) at the Field Museum of Natural History, 
GARDNER ET AL., PHYLOGENOMICS AND GENERIC REVISION OF MOREAE

240 and then additional samples were sequenced on a HiSeq $40002 \times 150 \mathrm{bp}$ run at the

241 Northwestern University Genomics Core.

242 We also included 47 Moraceae and Urticaceae samples enriched for the

243 Angiosperm353 probes and sequenced as part of the Plant and Fungal Trees of Life project

244 (PAFTOL, RBG Kew; https://www.kew.org/science/our-science/projects/plant-and-fungal-

245 trees-of-life; Table S1). Sample preparation and sequencing followed Johnson et al. (2019).

246 The PAFTOL samples were enriched with a universal probe set developed for angiosperms

247 (the "Angiosperms353").

248 Finally, we used samples sequenced for previous phylogenetics projects in Artocarpus

249 J.R. Forst. \& G. Forst. and Parartocarpeae Zerega \& E.M. Gardner to complete our

250 sampling (Johnson \& al., 2016; Gardner, 2017; Kates \& al., 2018; Zerega \& Gardner,

251 2019). The final dataset contained 247 samples.

252

253 Assembly of reads

254 We trimmed reads using Trimmomatic (ILLUMINACLIP: TruSeq3-PE.fa:2:30:10

255 HEADCROP:3 LEADING:30 TRAILING:25 SLIDINGWINDOW:4:25 MINLEN:20)

256 (Bolger \& al., 2014) and assembled them with HybPiper, which produces gene-by-gene,

257 reference-guided, de novo assemblies (Johnson \& al., 2016). For the samples enriched with

258 the Angiosperms353 baits, we used the reference described by Johnson et al. (2019), and

259 for the samples enriched with the Moraceae333 baits, we used the reference described in

260 Zerega \& Gardner (2019). To increase overlap between the two data sets beyond the 5

261 genes they inherently have in common, we used HybPiper to assemble the

262 Angiosperms353-enriched reads using the Moraceae333 targets and vice-versa, in order to

263 capture any additional genes found in off-target reads. The exception was most of the

264 Artocarpus data set, which was previously assembled for another study using only the

265 Moraceae333 targets. We used the HybPiper script "intronerate.py" to build "supercontig"

266 sequences for each gene, consisting of exons as well as any assembled flanking non-coding

267 sequences (intronic or intergenic). To these new assemblies, we added 76 Moraceae333

268 assemblies from Gardner (2017) to complete sampling for the Artocarpeae. 
GARDNER ET AL., PHYLOGENOMICS AND GENERIC REVISION OF MOREAE

Main phylogenetic analyses

The full data set was analyzed using the "exon" sequences to ensure good alignment across the entire family. To maximize phylogenetic resolution within Moreae, a smaller data set consisting only of Moreae taxa and a single outgroup taxon (Artocarpus heterophyllus) was analyzed using the "supercontig" sequences but following the same methodology. For each of the 686 genes assembled, we discarded sequences shorter than $25 \%$ of the average length for the gene and discarded genes containing sequences for less than 30 samples. We aligned each gene with MAFFT (Katoh \& Standley, 2013)and used Trimal (Capella-Gutiérrez \& al., 2009) to discard sequences with an average pairwise identity of less than 0.5 to all other sequences in the alignment (indicative of poor a poor quality sequence that could not be properly aligned) as well as columns containing more than 75\% gaps. We used RAxML 8.2.4 (Stamatakis, 2014) to estimate a maximumlikelihood tree for a partitioned supermatrix of all genes as well as for each gene individually (GTRCAT model, 200 bootstrap replicates). We then used ASTRAL-III (Zhang \& al., 2017), a summary-coalescent method, to estimate a species tree from all gene trees, estimating node support using both bootstrap (160 replicates, resampling across and within genes) and local posterior probability (normalized quartet scores, representing gene tree concordance). Finally, we used ASTRAL-III to test whether, for each node, the null hypothesis of a polytomy could be rejected (Sayyari \& Mirarab, 2018). Alignment, trimming, and estimation of gene trees were parallelized using GNU Parallel (Tange, 2018).

\section{Whole chloroplast phylogenetic tree}

We also built a whole-chloroplast phylogenetic tree as follows. Rather than assembling full-length genomes, which can be extremely slow to align, we assembled and aligned the genomes in sections, dramatically speeding up the process. We created HybPiper targets using the chloroplast genome of Morus indica L. (NCBI RefSeq accession no. NC_008359.1) and the associated gene annotations. Each target consisted of a gene feature concatenated with any internal or subsequent non-coding sequence, terminating one base before the next gene feature began. These intervals were generated by manually 
GARDNER ET AL., PHYLOGENOMICS AND GENERIC REVISION OF MOREAE

300 editing the NCBI gff3 file in Excel (Microsoft Corp., Redmond, Washington, USA) and

301 then extracted using BedTools (Quinlan \& Hall, 2010). Assemblies for all Moraceae

302 samples and Boehmeria nivea (L.) Gaudich. were carried out in HybPiper using a coverage

303 cutoff of 2 and otherwise with default parameters. Within each target, sequencing less than

$30425 \%$ of the average length were discarded, and after alignment with MAFFT, sequences

305 with an average pairwise identity of less than 0.7 were discarded (the higher cutoff

306 reflecting the conserved nature of chloroplast DNA). Alignments were then concatenated

307 into a supermatrix, and samples with more than $50 \%$ undetermined characters were

308 discarded. Alignments were then rebuilt, filtered, and concatenated, and columns in the

309 final supermatrix with more than $75 \%$ missing characters were discarded. A maximum-

310 likelihood tree was generated using RAxML 8.2.4 under the GTRCAT model, with 200

311 rapid bootstrap replicates.

312

313 Phylogenetic network analysis

314 To further investigate relationships within the Paratrophis clade, including the proper

315 placement of Morus insignis and Trophis philippinensis (Bureau) Corner, we constructed

316 phylogenetic networks based on two reduced 8-taxon datasets ("exon" and "supercontig")

317 consisting of those taxa plus Streblus anthropophagorum (Seem.) Corner, S. glaber (Merr.)

318 Corner, S. glaber subsp. australianus (C.T. White) C.C. Berg, and S. heterophyllus (Blume)

319 Corner, with S. mauritianus (Jacq.) Blume as the outgroup. Alignment preparation followed

320 the workflow outline above except that only genes with sequences for all eight taxa were

321 retained. Rooted gene trees were used to infer the network in PhyloNet using the

322 "InferNetwork_MPL" command, allowing a maximum of four hybridization events and

323 collapsing gene tree nodes with less than 30\% bootstrap support (Yu \& Nakhleh, 2015;

324 Wen \& al., 2018) (Wen et al., 2018; Yu and Nakhleh, 2015); AIC was scored for the best

325 five networks from 10 runs, using the number of branch lengths and hybridization events

326 calculated as the number of parameters (Kamneva \& al., 2017).

328 ITS and rbcL phylogenetic trees 
GARDNER ET AL., PHYLOGENOMICS AND GENERIC REVISION OF MOREAE

While we did not have our own sequences for Streblus tonkinensis (Eberh. \& Dubard) Corner, S. ascendens Corner, S. banksii (Cheeseman) C.J. Webb, and S. smithii (Cheeseman) Corner, either ITS or $r b c L$ sequences existed in NCBI GenBank for these taxa (Fig. S2). We were not able to examine the underlying specimens ourselves, but we considered the chances of misidentification low because those species are morphologically and/or geographically distinctive. We constructed ITS and $r b c L$ data sets from our own samples using HybPiper, using Streblus sequences for these loci (obtained from GenBank) as targets and reducing the coverage cutoff at 2 to recover the loci from off-target reads. To these sequences, we added GenBank sequences of Streblus taxa as well as Trophis caucana (Pittier) C.C. Berg. For each locus, we aligned sequences with MAFFT, discarded short sequences ( $<490 \mathrm{bp}$ ), trimmed alignments to remove columns with over $75 \%$ gaps, and built maximum-likelihood trees using RAxML (GTRGAMMA, 1000 rapid bootstraps).

\section{Divergence time estimation}

The supermatrix maximum-likelihood tree was time calibrated using ape v 5.3 (Paradis \& Schliep, 2019) in R v 3.5.1 (Team, 2019). First, the tree was pruned of duplicate taxa and non-Moraceae outgroup taxa, and edge lengths (in substitutions per site) were multiplied by the number of sites in the alignment (to convert them to substitutions). The following stem nodes were constrained with minimum ages (in million years, Ma) based on fossil data, following(Zhang \& al., 2019): Ficus, 56 Ma; Broussonetia, 33.9 Ma; Morus (subg. Morus, based on U.S.S.R. locality of the fossil), 33.9 Ma; and Artocarpus, 64 Ma. The crown node of Moraceae was constrained to a minimum age of 73.2 $\mathrm{Ma}$ and a maximum age of 84.7 Ma.(Zhang \& al., 2019), which had a more extensive outgroup sampling that we have here. The tree was then time-calibrated using the chronos function under two different models ("relaxed" and "correlated") (Kim \& Sanderson, 2008; Paradis, 2013). The smoothing parameter $(\lambda)$ was chosen using the cross-validation method in the chronopl function (testing $\lambda=0$ and 0-5 through 1015), selecting the value of $\lambda$ that minimized the cross-validation statistic (Sanderson, 2002). The resulting trees were visualized using the densiTree function in phangorn 2.4.0 (Schliep, 2011), and the time calibrated tree representing the central tendency of these analyses was selected for use in all 
GARDNER ET AL., PHYLOGENOMICS AND GENERIC REVISION OF MOREAE

359 further analyses, also taking into account the results of past family-wide studies. As the

360 penalized likelihood approach used does not integrate over model uncertainty or

361 uncertainty in calibration placement and timing, confidence intervals on node ages are not

362 provided in this study. A geologic timescale based on the strat2012 dataset added to tree

363 figures using PHYLOCH v 1.5-3 (Heibl, 2008).

Ancestral state reconstruction for inflexed stamens

All taxa were coded for presence (1) or absence (0) of inflexed stamens in bud.

367 Taxa such as Dorsteniae with stamens that are inflexed in bud but gradually straighten were

368 coded as 0 . We reconstructed ancestral character states on the entire phylogeny by

369 stochastic mapping using the make.simmap function in the phytools v 0.6-99 (Revell,

370 2012). We also tested for trait-associated shifts in diversification rates using BAMM v

3712.5 .0 (Rabosky \& al., 2013, 2014a; Rabosky, 2014), specifying the amount of missing taxa

372 per clade to account for the high proportion of missing taxa in Ficeae, Castilleae, and

373 Dorstenieae. Parameters were optimized using BAMMtools v 2.1.7 (Rabosky \& al.,

374 2014b). We also tested for trait-dependent diversification using diversitree v 0.9-13

375 (FitzJohn, 2012). We evaluated BiSSE and trait-independent models on the entire tree and

376 on a pruned tree consisting only of the densely-sampled Maclureae+Moreae+Artocarpeae

377 clade.

378 Reads from have been deposited in Genbank (Non-PAFTOL samples: BioProject

379 PRJNA322184; PAFTOL samples: BioProject PRJEB35285, subprojects PRJEB37667 for

380 Moraceae and PRJEB37665 for Urticaceae). Tree files and scripts outlining the

381 phylogenetic analyses have been deposited in the Dryad Data Repository (\#\#\#TBA\#\#\#).

382

383 Results

$384 \quad$ The final data set contained 247 samples, 47 enriched with the Angiosperms 353

385 baits, 196 enriched with the Moraceae333 baits, and 4 extracted from whole genomes) and

386619 genes (286 Angiosperms353 and all of the Moraceae333) (Table S1). The "exon"

387 supermatrix (all taxa) contained 613,126 characters, and the "supercontig" supermatrix 
GARDNER ET AL., PHYLOGENOMICS AND GENERIC REVISION OF MOREAE

388 (Moreae and select outgroup taxa only) contained 799,926 characters. The chloroplast data set contained 113 loci.

On average, we assembled 39 Moraceae333 genes from the Angiosperms353enriched samples and 20 Angiosperms353 genes from the Moraceae333-enriched samples, and the average pairwise overlap in assembled loci was 210 (Tables S1, S2). Nineteen taxa were represented in both sets of samples, and 15 of these were always monophyletic (Figs. 2, 3). Twelve resolved as sister pairs: Antiaropsis decipiens (31 loci overlapping), Bagassa guianensis Aubl. (38), Batocarpus amazonicus (Ducke) Fosberg (22), Batocarpus orinocensis H. Karst. (34), Brosimum alicastrum Sw. (42), Clarisia racemosa Ruiz \& Pav. (59), Maclura africana (Bureau) Corner (213), Milicia excelsa (Welw.) C.C. Berg (45),

398 Streblus asper (Retz.) Lour. (75), Streblus mauritianus (Jacq.) Blume (40), Streblus

399 usambarensis (Engl.) C.C. Berg (43), and Trophis caucana (32). Three more represented

400 by more than two samples always resolved as a clade: Sorocea bonplandii (Baillon) W.C.

401 Burger, Lanj. \& de Boer (3 samples; 19-35 loci overlapping), Maclura tinctoria (L.) D.

402 Don ex Steud. (4 samples; 37-43 loci overlapping), and Malaisia scandens (Lour.) Planch.

403 (3 samples; 27-43 loci overlapping). Three additional taxa resolved as sister pairs in the

404 ASTRAL analysis but as a grade in the supermatrix analysis: Maclura cochinchinensis

405 (Lour.) Corner (28 loci overlapping), Streblus heterophyllus (Blume) Corner (50), and

406 Trophis montana (Leandri) C.C. Berg (56). Only one species, Utsetela gabonensis Pellegr.

407 (18 loci overlapping) was never monophyletic, always forming a grade with $U$. neglecta 408 Jongkind.

409 The supermatrix and species trees were broadly concordant except within

410 Artocarpus, where the species tree was much more consistent with previous analyses within 411 that genus (Gardner et al., in review) (Figs. 2, 3). Otherwise, most differences were at 412 shallow phylogenetic depths, such as relationships within Streblus section Paratrophis. For 413 both data sets, the polytomy hypothesis was rejected $(P<0.05)$ for Moraceae and all tribe 414 and genus-level clades (following the revised classification presented below) (Figs. 2, 3).

415 Of the genera in Moreae sensu Clement \& Weiblen, only Milicia and Sorocea were 416 monophyletic; Morus, Streblus, and Trophis were not; Bagassa is monotypic and resolved 417 as sister to Sorocea, with which it shares straight stamens. Four Moreae species resolved 
GARDNER ET AL., PHYLOGENOMICS AND GENERIC REVISION OF MOREAE

418 with other tribes: Trophis caucana was nested within Castilleae, Streblus asper (Retz.)

419 Lour. was sister to Castilleae, Streblus indicus (Bureau) Corner was sister to

420 Parartocarpeae, and Streblus usambarensis was nested within Dorstenieae. Moreae was

421 otherwise monophyletic, comprising the following subclades: (1) Streblus section

422 Taxotrophis, sister to all other Moreae; (2) (a) Trophis section Maillardia, (b) Milicia +

423 Morus subgenus Afromorus, (c) Streblus section Ampalis, (d) Streblus section Paratrophis

424 in part + Morus subgenus Gomphomorus, (e) Streblus section Paratrophis in part + Trophis

425 section Calpidochlamys; (3) Bagassa + Sorocea; (4) Trophis sections Trophis and

426 Echinocarpa C.C. Berg + Morus. These are roughly geographic clades: (1) Southeast Asia;

427 (2) (a) Madagascar, (b) Southeast Africa, (c) Madagascar, (d) Pacific + South America, (e)

428 Southeast Asia + Pacific; (3) South America; (4) South America.

429 While Trophis philippinensis was inside the Paratrophis clade in all analyses, the

430 position of Morus insignis was not stable. In the "exon" analyses, it was always in

431 Paratrophis (Fig. 2), although the polotomy hypothesis could not be rejected for its

432 position as sister to $S$. anthropophagorum + S. heterophyllus. In the "supercontig" and

433 chloroplast analyses, it was sister to Paratrophis, and the polotomy test was rejected for

434 that node (Figs. 3, S1). In the five phylogenetic networks reported (Fig. 4, Table S3), $M$.

435 insignis was inside Paratrophis in three of them, had a hybrid origin involving Paratrophis

436 in one, and was only unambiguously sister to Paratrophis in one network, although even in

437 that one it was involved in a hybridization involving Paratrophis.

438 The chloroplast phylogenetic tree (Fig. S1) was generally in agreement with the

439 nuclear phylogenetic trees, with three notable differences. Streblus indicus and the

440 Parartocarpeae formed a grade paraphyletic to Dorstenieae, Castilleae, and Ficeae, rather

441 than a clade. Streblus zeylanicus (Thwaites) Kurz was sister to S. taxoides (B. Heyne ex

442 Roth) Kurz (instead of sister to all of section Taxotrophis), although with low support

443 (62\%), and S. glaber subsp. australianus was not sister to subsp. glaber, although its

444 placement was not strongly supported (80\%). Finally, Morus insignis was sister to

445 Paratrophis, agreeing with the "supercontig" analysis but not the "exon" analysis.

446 The ITS and $r b c \mathrm{~L}$ phylogenetic trees based on few characters, were not very well

447 resolved, with only few nodes attaining 100\% bootstrap support (Fig. S2). Nevertheless, 
GARDNER ET AL., PHYLOGENOMICS AND GENERIC REVISION OF MOREAE

448 with the exception of a few stray taxa (one Dorstenia sample in ITS and one Streblus

449 indicus samples in $r b c \mathrm{~L})$, both phylogenetic trees reconstructed monophyletic tribes with at

450 least moderate support. In the ITS phylogenetic tree, Streblus smithii and S. banksii were

451 both in a well-supported clade comprising section Paratrophis, and S. tonkinensis was part

452 of the Castilleae clade, which also contained S. asper and Trophis caucana. In the rbcL

453 phylogenetic tree, the two Streblus ascendens samples, the four samples of the

454 undetermined Streblus from Papua New Guinea, and S. smithii were part of a well-

455 supported clade comprising section Paratrophis.

\section{Time-calibration and ancestral state reconstruction}

458 The cross-validation criterion was minimized by a smoothing parameter $(\lambda)$ value of

459 106. The tree calibrated under the correlated model $(\log \operatorname{Lik}=-17 ; \mathrm{p}-\log \mathrm{Lik}=-17 ; \Phi \mathrm{IC}=$

460 1108) was less sensitive to changes in $\lambda$ and generally had younger ages than the tree

461 calibrated under the relaxed model $(\log L i k=-56.7 ; \mathrm{p}-\log \operatorname{Lik}=-53129706, \Phi \mathrm{IC}=$

462 4209013), the latter of which had perhaps implausibly long terminal branches (Table 2, Fig.

463 S3). The crown age of Moreae was Paleocene (59.1 Ma) under the correlated model and

464 late Cretaceous (75.4 Ma) under the relaxed model. Because the correlated tree was more

465 consistent with past family-wide studies (Zerega \& al., 2005; Zhang \& al., 2019), we used

466 that tree for all further analyses (Fig. 5). The BAMM analysis found a single credible rate

467 shift, not surprisingly at the crown node of Ficus (Fig. S4); that rate shift was-also not

468 surprisingly — associated with a loss of inflexed stamens, which are never found in Ficus ( $P$

$469=0.035)$; no rate shifts were found within Moreae. Ancestral reconstruction on the entire

470 tree found that ancestral Moraceae had stamens inflexed in bud; these were lost nine times

471 (in Ficeae, Olmedieae [=Castilleae], Parartocarpeae, twice in Dorstenieae, Maclura section

472 Cudrania (Trécul) Corner, Artocarpeae, Bagassa, and Sorocea) and regained once (in

473 Trophis caucaua) (Fig. 6). Model testing on both the whole tree and on the

474 Moreae+Artocarpeae+Maclureae subtree indicated that a BiSSE model was not

475 substantially better than a trait-independent model (Moreae only: AIC for BiSSE $=1110.4$;

476 trait-independent $=1112.8 ; \Delta \mathrm{AIC}=2.4$; whole family: $\mathrm{AIC}$ for $\mathrm{BiSSE}=1488.3$; trait- 
GARDNER ET AL., PHYLOGENOMICS AND GENERIC REVISION OF MOREAE

477 independent $=1490.4 ; \Delta \mathrm{AIC}=2.1)$. In any event, the reconstructions were identical (Figs.

478 6).

\section{Discussion}

Sequencing and combination of data sets

This study was materially improved by our ability to combine samples enriched

with two largely non-overlapping bait sets. Despite minimal by-design overlap, we were able to assemble many overlapping loci for samples with moderate to deep coverage (Table S2), adding taxa that would not otherwise have been included in the study and replicating taxa to confirm unexpected phylogenetic placement (e.g, Streblus indicus). Taxa replicated across the two data sets performed well in phylogenetic analyses, with 15 out of 19 always

490 resolving as monophyletic in supermatrix analyses and 18/19 so resolving in ASTRAL

491 analyses, with only Utsetela gabonensis always forming a grade instead (with a difficult-to-

492 distinguish congener). Our results should embolden others to combine and repurpose data

493 sets in similar ways.

\section{Higher taxonomy in Moraceae and the delimitation of the tribe Moreae}

Our results support Corner's overall approach to the classification of Moraceae, if

497 not all of its details, including the primacy of inflorescence architecture and the

498 unreliability of inflexed stamens for higher taxonomy (Corner, 1962). Inflexed stamens are

499 a plesiomorphy that was lost nine times in Moraceae (Fig. 6), a preserved ancestral

500 character whose past taxonomic importance accounts for the rather extreme non-

501 monophyly of the Moreae. Streblus s.l. provides the best illustration of this principle,

502 appearing in four out of seven tribe-level clades within Moraceae. We may justly call its

503 disparate sections, as Corner did, "fragments of an ancestral Streblus." (Corner, 1975)—or

504 in modern parlance, a paraphyletic remnant preserving plesiomorphic staminate flowers

505 similar to those likely to have occurred in the ancestor of all Moraceae, with four free tepals

506 and four inflexed stamens (Clement \& Weiblen, 2009). If one of the goals of modern 
GARDNER ET AL., PHYLOGENOMICS AND GENERIC REVISION OF MOREAE

507 systematics is to establish taxonomic frameworks that reflect as far as possible real

508 evolutionary relationships, our results may serve as a warning to carefully investigate

509 whether characters used for taxonomy are derived (synapomorphic) or ancestral

510 (symplesiomorphic).

511 Broadly speaking, a tribal delimitation based on inflorescence architecture

512 (supplemented with other characters in some cases) agrees best with the phylogenetic trees

513 presented here. Moreae (as revised below) have unisexual spicate or racemose

514 inflorescences (the pistillate ones sometimes uniflorous), with the globose-capitate pistillate

515 inflorescences of the monotypic Bagassa as the sole exception. Stamens may be either

516 inflexed or straight. Elsewhere in the family, racemes and spikes are rare, with the former

517 found in Maclura (in part) and the latter found in the related genera Broussonetia,

518 Allaeanthus Thwaites, and Malaisia and arguably in Batocarpus H. Karst. and Clarisia; all

519 of these have capitate pistillate inflorescences. The taxa of Streblus s.1. and Trophis s.l. that

520 must be excluded from Moreae all have inflorescences that do not fit our general rule:

521 discoid-capitate (Streblus asper and Trophis caucana), cymose (Streblus indicus), or

522 bisexual (Streblus usambarensis). In these cases, perhaps Corner did not take his emphasis

523 on inflorescence architecture quite far enough, including too wide of a variety in this one

524 tribe. In critiquing the utility of inflorescence architecture for classification, Berg (1977b)

525 noted the similarity in the inflorescence structure of Bleekrodea (then part of Moreae, and

526 included in Streblus by Corner) to that of Utsetela and Helianthostylis (Dorstenieae), an

527 observation that proved prescient when Bleekrodea was found to belong to Dorstenieae

528 (Clement \& Weiblen, 2009).

529 Olmedieae (as revised below, including Castilleae) can be defined entirely based

530 upon the presence of a discoid inflorescence subtended by an involucre of imbricate bracts.

531 Two species with such involucres previously classified as Moreae, Streblus asper and

532 Trophis caucana (=Olmedia aspera) always appeared in the Olmedieae (=Castilleae) clade

533 in our analyses (Figs. 2-3). Olmedia aspera (=Trophis caucana) - the nomenclatural type

534 of the tribe Olmedieae — was transferred to Moreae because of its inflexed stamens and lack

535 of self-pruning branches (Berg, 1977b). In inflorescence morphology, however, T. caucana

536 closely resembles other Castilleae, always subtended by an involucre of imbricate bracts 
GARDNER ET AL., PHYLOGENOMICS AND GENERIC REVISION OF MOREAE

537 (Berg, 1977b, 2001). The staminate inflorescences of Streblus asper are strikingly similar

538 to those of T. caucana, and it is remarkable that the affinity between $S$. asper and the

539 Olmedieae has not been seriously considered until now. Previous barcoding or phylogenetic

540 studies have placed Trophis caucana (Kress \& al., 2009) and Streblus tonkinensis (Chen \&

541 al., 2016) (closely allied to $S$. asper) in the Castilleae clade, but those results went

542 unremarked upon, perhaps because of the broad scale of the studies (respectively, forest

543 community phylogenetics and the vascular plants of China).

The remaining five tribes can all be broadly defined based on inflorescence

architecture as Corner argued, sometimes supplemented by other characters as Berg

546 preferred, allowing of course for the exceptions made inevitable by the vicissitudes of

547 evolution. Ficeae of course is defined by the syconium (essentially an urceolate disc that

548 has been closed at the top). Maclureae have densely-packed globose infructescences and

549 can be distinguished from Artocarpeae by their four stamens (inflexed in most sections) and

550 armature. Artocarpeae also have densely-packed globose infructescences but only one

551 straight stamen and no armature. Parartocarpeae have a few connate involucral bracts and

552 (in large part) flowers embedded in fleshy receptacles. Dorstenieae are perhaps the most

553 heterogenous group, but in large part they have bisexual inflorescences, often capitate or

554 discoid, and often with ballistically-ejected endocarps.

The role of inflexed stamens in the evolution of Moraceae

The repeated losses of inflexed stamens (Fig. 6), which are associated with wind

558 pollination (Bawa \& Crisp, 1980; Berg, 2001), raise the possibility that transitions from

559 wind to animal pollination, which have already been documented in Moraceae (Momose \&

560 al., 1998; Sakai \& al., 2000; Datwyler \& Weiblen, 2004; Gardner \& al., 2018), are even

561 more common within the family. Generally considered rare (Culley \& al., 2002), the shift

562 from wind to animal pollination may be a repeated feature of Moraceae deserving of further

563 investigation. Further investigation of Sorocea, with its straight stamens and sometimes-

564 scented inflorescences, may reveal that, like Artocarpus, it contains both wind and animal

565 pollination. And while little is known about pollination in the Dorstenieae, the presence of

566 unisexual inflorescences and inflexed stamens (e.g., Broussonetia) as well as bisexual 
GARDNER ET AL., PHYLOGENOMICS AND GENERIC REVISION OF MOREAE

567 inflorescences with straight stamens (e.g., Brosimum, Dorstenia) raises the possibility of

568 transitions within that clade as well; taxa with inflexed stamens but bisexual inflorescences

569 such as Bleekrodea and Sloetia (which is visited by bees, EMG pers. obs.) may represent

570 remnants of an intermediate state. Finally, the conclusion that a single transition to insect

571 pollination preceded the split between the Ficeae and Olmedieae (Castilleae) should be

572 reevaluated in light of the position of Streblus asper as sister to the latter (Figs. 2, 3). The

573 only shift in diversification rates our analyses recovered was on the branch leading to the

574 very diverse Ficus, suggesting that the shift away from wind pollination may not by itself

575 lead to increased diversification.

\section{Explanation of taxonomic revisions}

We present a generic revision of Moreae (Fig. 7) based on the present phylogenetic study as well as morphological characters. Arranging monophyletic and morphologically coherent genera requires one change of rank and 8 new combinations, but no entirely new names. These revisions provide a framework for within-genus revisionary work, which will require more intensive sampling and review of specimens within the genera circumscribed

583 here. We provide an explanation of the taxonomic changes, followed by a formal presentation of the affected tribes and genera, with complete species lists and synonymy.

Trophis and the reinstatement of the Olmedieae — To make Trophis monophyletic,

586 we propose that it be applied strictly to the Neotropical clade that includes the type species

587 Trophis americana L. (=Trophis racemosa (L.) Urb.). To accomplish this, we reinstate the 588 genus Maillardia and transfer Trophis philippinensis to Paratrophis (discussed below),

589 reinstating its former name Paratrophis philippinensis (Bureau) Fern.-Vill. Because

590 Trophis caucana does not belong in Trophis or Moreae but rather with the members of

591 Castilleae, we reinstate its former name Olmedia aspera Ruiz \& Pav. and transfer it to that 592 tribe, whose former name Olmedieae must now be reinstated on account of its priority.

593 Streblus - We restrict the genus Streblus to three species comprising most of 594 section Streblus — Streblus asper, Streblus tonkinensis, and Streblus celebensis C.C. Berg595 and transfer the genus to Olmedieae. Although S. celebensis was not included in our 596 phylogeny, the sub-involucrate inflorescences are similar to those of $S$. asper, with which $S$. 
GARDNER ET AL., PHYLOGENOMICS AND GENERIC REVISION OF MOREAE

597

598

599

600

601

602

603

604

605

606

607

608

609

610

611

612

613

614

615

616

617

618

619

620

621

622

623

624

625

626

celebensis differs primarily in vegetative characters, the latter having broadly-toothed margins in the distal half of the leaf. Both occur in Sulawesi, where at least one specimen with intermediate leaf morphology has been collected (Sulawesi, Kendari: Kjellberg 452, 24 Feb. 1929, L, det. S. asper by E.J.H. Corner). We therefore retain its taxonomic position in Streblus. The remaining member of section Streblus, S. usambarensis, belongs with Dorstenieae, and we therefore transfer it to that tribe, reinstating its former name Sloetiopsis usambarensis. Streblus indicus is sister to Parartocarpeae, and we therefore reinstate its former name Pseudostreblus indicus and transfer it to Parartocarpeae.

The remaining species of Streblus s.l. are properly placed in Moreae but are still paraphyletic. We therefore reinstate the genera Ampalis, Paratrophis, and Taxotrophis, largely corresponding to the former sections but requiring some new combinations.

Paratrophis as presented here is united by spicate male inflorescences (usually) with peltate or reniform bracts (except for Paratrophis philippinensis (=Trophis philippinensis), which does not have fleshy tepals in fruit). Within Paratrophis we include Paratrophis ascendens (Corner) E.M. Gardner (=Streblus ascendens Corner) based on its inflorescence morphology and phylogenetic position in the $r b c \mathrm{~L}$ tree (Fig. S2b). Its previous position within the monotypic section Protostreblus was due to the type specimen's spiral phyllotaxy, but the latter may be atypical, as a more recent collection Womersley NGF 24791 (K, L, BO), has distichous leaves. Berg (1988), recognizing the close affinity between Pachytrophe dimepate Bureau and Ampalis mauritiana, included both in Streblus section Ampalis. Our phylogenetic results support this grouping, which we maintain in the reinstated genus Ampalis, requiring one new combination. We follow Baillon in maintaining Pachytrophe as a section of Ampalis in order to recognize the differences between them in phyllotaxy, stipule amplexicaulity, and embryo characters. Further intensive study of that species complex may of course warrant a different approach, including potentially reducing both to a section of Paratrophis. Our species lists within the former components of Streblus follow Berg's approach $(1988,2006)$, with two exceptions. We provisionally recognize Taxotrophis zeylanica (Thwaites) Thwaites as distinct from Taxotrophis taxoides (B. Heyne ex Roth) W.L. Chew ex E.M. Gardner (=Streblus taxoides (B. Heyne ex Roth) Kurz) based on our phylogenetic work and following the Flora of 
GARDNER ET AL., PHYLOGENOMICS AND GENERIC REVISION OF MOREAE

627 China, which recognizes Streblus zeylanicus as distinct from $S$. taxoides based on its

628 clustered pistillate inflorescences. In addition, we provisionally recognize Paratrophis

629 australiana (=S. glaber subsp. australianus) as distinct from Paratrophis glabra based on

630 its geographic and consistent morphological distinctiveness. Taxotrophis and Paratrophis

631 warrant further investigation to refine species limits.

632 Morus - Morus has never been revised, and the species concepts are often based on

633 minor morphological differences (Berg et al., 2006; Berg 2001), and the paraphyly of

634 several species in our analyses suggests that a broad M. alba similar to Bureau's (1873)

635 may be worth a second look. The monotypic subgenus Afromorus is sister to Milicia, but

636 the leaf morphology is markedly different, instead resembling other Morus species in its

637 trinerved based and crenate margins. We therefore raise Afromorus to genus level, requiring

638 one new combination. Morus insignis, from western Central and South America, bears a

639 remarkable resemblance to Paratrophis, in particular P. pendulina, especially in leaf

640 morphology, which in $M$. insignis is not consistently trinerved as in other mulberries. The

641 infructescence appears superficially like a mulberry because of its basally fleshy tepals,

642 although with more loosely-packed flowers, but closer inspection places it firmly within

643 Paratrophis, with drupes protruding from the persistent tepals, peltate bracts, and a sterile

644 groove. Because analyses differ as to whether M. insignis is sister to Paratrophis or part of

645 it, it seems best to treat them as congeners.

646 These changes result in ten monophyletic genera of Moreae, providing a framework

647 for revisionary work within the genera. Below, we present a complete genus and species list

648 for Moreae with brief descriptions for all genera and synonymies for new combinations and

649 reinstated or recircumscribed taxa. All cited protologues were reviewed, and dates for

650 works published piecemeal were confirmed by reference to Taxonomic Literature 2 online

651 (https://www.sil.si.edu/DigitalCollections/tl-2/index.cfm).

652

653

654 Taxonomic Treatment

655

656 Key to the tribes of Moraceae 
GARDNER ET AL., PHYLOGENOMICS AND GENERIC REVISION OF MOREAE

658 This key follows the tribal circumscription of Clement \& Weiblen (2009), as subsequently

659 modified by Zerega \& al. (2010), Chung \& al. (2017), Zerega \& Gardner (2019), and this

660 study.

661

662

1. Inflorescence a syconium (urceolate with the opening entirely closed by ostiolar

663 bracts, flowers enclosed at all stages of development) - Ficeae (Ficus)

664

1. Inflorescence not a syconium (capitate, spicate, discoid, or urceolate, but

665 flowers not entirely enclosed at all developmental stages) -2

666

2. Inflorescences (at least staminate) with an involucre of imbricate bracts; often with self-pruning horizontal branches (except Olmedia, Poulsenia, Streblus) Olmedieae (Antiaris, Antiaropsis, Castilla, Helicostylis, Maquira, Mesogyne, Naucleopsis, Olmedia, Perebea, Poulsenia, Pseudolmedia, Sparattosyce, Streblus)

3. Plants woody; dioecious; pistillate inflorescences globose-capitate; spines axillary or terminating short shoots - Chlorophoreae (Maclura)

3. Plants woody, herbaceous, or succulent; dioecious or monoecious; pistillate inflorescences various; spines absent or if present, then pistillate inflorescences not globose capitate -4

4. Trees or shrubs; monoecious; inflorescences unisexual; staminate flowers with one stamen (rarely two) - Artocarpeae (Artocarpus, Batocarpus, Clarisia)

4. Trees, shrubs, lianas, herbaceous, or succulent; monoecious or dioecious; inflorescences unisexual or bisexual; staminate flowers with more than one stamen (or if one stamen then dioecious) -5 
GARDNER ET AL., PHYLOGENOMICS AND GENERIC REVISION OF MOREAE

686

687

688

689

690

691

692

693

694

695

696

697

698

699

700

701

702

703

704

705

706

707

708

709

710

Revisions

711

712

713

714 Moreae Gaudich. in Freyc., Voy. Uranie, Bot. (1830) 509. Parartocarpus, Pseudostreblus) staminate flowers never 5-parted - 6 Trymatococcus, Utsetela) ejected -7 Sorocea, Trophis)

\section{Tribe MOREAE}

5. Trees or shrubs; monoecious; inflorescences unisexual; stamens straight in bud or staminate flowers 5-parted and inflexed in bud - Parartocarpeae (Hullettia,

5. Trees, shrubs, lianas, herbaceous, or succulent; monoecious or dioecious; inflorescences bisexual or unisexual; stamens straight or inflexed in bud but

6. Trees, shrubs, lianas, herbaceous, or succulent; inflorescences bisexual (or if unisexual then a climber or herbaceous); endocarp body often ballistically ejected from infructescence - Dorstenieae in part (Allaeanthus in part, Bleekrodea, Bosqueiopsis, Brosimum, Broussonetia in part, Dorstenia, Fatoua, Helianthostylis, Malaisia, Scyphosyce, Sloetia, Sloetiopsis, Treculia, Trilepsium,

6. Trees or shrubs; inflorescences unisexual; endocarp body never ballistically

7. Trees; stamens inflexed in bud; pistillate inflorescences globose-capitate Dorstenieae in part (Allaeanthus in part, Broussonetia in part)

7. Trees or shrubs; stamens inflexed or straight in bud; pistillate inflorescences various, not globose-capitate if stamens are inflexed in bud-Moreae (Afromorus, Ampalis, Bagassa, Maillardia, Milicia, Morus, Paratrophis, Taxotrophis, 
GARDNER ET AL., PHYLOGENOMICS AND GENERIC REVISION OF MOREAE

715 Moreae subtribe Soroceae Miq in Martius, Fl. Bras. 4, 1, fasc. 12: 111 (1853), p.t. -

716 Soroceae (Miq.) C.C. Berg, Blumea 50: 537 (2005), p.p.

717 Strebleae Bureau in DC., Prodr. 17: 215 (1873), p.p.

719 Tree or shrubs, monoecious or dioecious. Leaves alternate or opposite, distichous or

720 spirally arranged; stipules lateral to amplexicaul. Inflorescences unisexual, uniflorous or

721 racemose, spicate, capitate, or globose; bracteate; tepals 4, free to connate; staminate

722 flowers with 4 stamens, filaments straight or inflexed in bud, pistillode usually present;

723 pistillate flowers with (mostly) free ovary, 2 stigmas. Fruits drupaceous or achene-like

724 with a fleshy persistent perianth, dehiscent or not. Seeds with or without endosperm, testa

725 usually with a thick vascularized part below the hilum, cotyledons equal or unequal,

726 straight or folded.

728 Genera and distribution: ten genera and 63 species with a worldwide distribution.

\section{Afromorus}

Afromorus E.M. Gardner, gen. nov. - based on Morus L. subg. Afromorus [A. Chev., Rev. Bot. Appl. Agr. Trop. 29 (315-316): 70 (1949), invalidly published]; J.-F. Leroy, Rev. Bot. Appl. Agr. Trop. 29 (323-324): 482 (1949) \& Bull. Mus. Hist. Nat. Paris, ser. 2, 21: 732 (1949). TYPE: Afromorus mesozygia (Stapf ex A. Chev.) E.M. Gardner.

Dioecious trees, shoot apices deciduous. Leaves distichous, triplinerved or at least trinerved at the base. Stipules free, more or less lateral. Inflorescences solitary or paired, bracts of varying shapes. Staminate inflorescences spicate, to $2.5 \mathrm{~mm}$ long, flower 4-parted, tepals imbricate, ciliolate, pistillode small, apiculate. Pistillate inflorescences subglobose, ca. $5 \mathrm{~mm}$ across, flowers 4-parted, tepals ciliolate, stigma bifid, equal or unequal, arms filiform to $5 \mathrm{~mm}$ long. Infructescences subglobose or less often slightly 
GARDNER ET AL., PHYLOGENOMICS AND GENERIC REVISION OF MOREAE

elongate, ca. $1 \mathrm{~mm}$ across, tepals fleshy, yellowish to greenish, drupes ca. 5 x 3-5 mm. Seeds ca. 4.5 x 2.5-4.5 mm.

Species and distribution: one species, in tropical Africa.

Note: The leaves of Afromorus — with crenate margins and trinerved bases-bear a striking resemblance to those of Morus, and it is thus not surprising that the former was heretofore included within the latter. However, leaves of Afromorus are distinct in being usually completely triplinerved, without an upper pinnately-veined portion as in most species of Morus. As the genus is monotypic, the type must be its only species, Afromorus mesozygia (Stapf ex A. Chev.) E.M. Gardner.

The genus name is based on Leroy's invalidly published Morus subgenus Afromorus, which was published only in French without a Latin diagnosis or description as required under the Code.

1. Afromorus mesozygia (Stapf ex A. Chev.) E.M. Gardner, comb. nov. — based on Morus mesozygia Stapf ex A. Chev. [Végétaux utiles de l'Afrique tropicale française 5: 263 (1909), nomen solum], J. Bot. (Morot) ser. 2, t. 2: 99 (1909).

Celtis lactea Sim, For. Fl. Port. E. Afr. : 97, t. 96 (1909), probably post-dating Morus mesozygia (fide Berg. 1977) - Morus lactea (Sim) Mildbr., Notizbl. Bot. Gart. Berlin 8: 243 (1922) - Morus mesozygia var. lactea (Sim) A. Chev., Rev. Bot. Appl. Agr. Trop. 29: 72 (1949).

Morus mesozygia var. sanda A. Chev., Rev. Bot. Appl. Agr. Trop. 29: 71 (1949), invalidly published (under Art. 39.1, Latin description or diagnosis lacking). Morus mesozygia var. colossea A. Chev., Rev. Bot. Appl. Agr. Trop. 29: 71 (1949), invalidly published (under Art. 39.1, Latin description or diagnosis lacking).

\section{Ampalis}

Ampalis Bojer, Hort. Maurit. 291 (1837)

Streblus Lour. subgen. Parastreblus Blume, Mus. Bot. Ludg.-Bat. 2: 89 (1856) 
GARDNER ET AL., PHYLOGENOMICS AND GENERIC REVISION OF MOREAE

775

776

777

778

779

780

781

782

783

784

785

786

787

788

789

790

791

792

793

794

795

796

797

798

799

800

801

802

803

804

Streblus Lous. sect. Ampalis (Bojer) C.C. Berg, Proc. Kon. Ned. Akad. Wetensch. C 91(4): 358 (1988).

Pachytrophe Bureau, Prodr. [A.P. de Candolle] 17: 234 (1873). - Ampalis Boj. sect. Pachytrophe (Bur.) Baillon, Hist. Pl. 6: 191 (1875-76)

Dioecious trees or shrubs. Leaves distichous to spirally arranged, pinnately veined. Stipules free, nearly lateral. Inflorescences solitary or paired in the leaf axils, spicate, with an abaxial sterile groove, flowers in longitudinal rows, bracts basalt attached to subpeltate. Staminate inflorescences to $9 \mathrm{~cm}$ long, flowers 4-parted, decussate-imbricate, stamens 4 , inflexed in bud, pistillode present. Pistillate inflorescences to $12 \mathrm{~cm}$ long, tepals 4, separate, decussate-imbricate, ovary free, stigmas 2, equal. Infructescences with enlarged fleshy perianths ca. 6-8 mm long, surrounding drupaceous fruits, the latter ca. 5-6 mm long.

Seeds ca. $4 \times 4 \mathrm{~mm}$, testa thickened and not distinctly vascularized, cotyledons equal.

Species and distribution: Two species, native to Madagascar and Comoros.

Note: The two sections differ in their phyllotaxy (usually spiral in Ampalis and ditichous in Pachytrophe) and stipules (free in Ampalis, connate in Pachytrophe). Sect. Ampalis usually has somewhat larger inflorescences.

\section{Ampalis sect. Ampalis}

1. Ampalis mauritiana (Jacq.) Urb., Symb. Antill. 8: 165 (1920) - Morus mauritiana Jacq., Collect. 3: 206 (“1789”, 1791) - Streblus mauritianus (Jacq.) Blume, Mus. Bot. Lugd.-Bat. 2: 80 (1856).

Streblus maritimus Palaky, Catal. Pl. Madag. 2: 31 (1907)

Morus nitida Willem. In Useri, Ann. Bot. 18: 56 (1796)

M. ampalis Poir. In Lam., Encycl. Bot. 4: 380 (1797)

Trophis cylindrica Roxb., Fl. Indica 3: 599 (1832), pro syn. M. mauritianae. Ampalis madagascariensis, Bojer, Hort. Maurit. 291 (1837) nom. illeg., pro syn. 
GARDNER ET AL., PHYLOGENOMICS AND GENERIC REVISION OF MOREAE

Ampalis madagascariensis var. occidentalis Léandri, Mém. Inst. Sci. Madag., ser. B, 1: 12, pl. (1948).

Morus rigida Hassk., Cat. Hort. Bog. 74 (1844).

Ampalis Boj. sect. Pachytrophe (Bureau) Baillon, Hist. Pl. 6: 191 (1875-76) $\equiv$ Pachytrophe Bureau in A.DC, Prodr. 17: 234 (1873). - Type: Pachytrophe dimepate Bureau.

2. Ampalis dimepate (Bureau) E.M.Gardner, comb. nov., based on Pachytrophe dimepate Bureau in A.DC Prodr. 17: 234 (1873) - Streblus dimepate (Bureau) C.C.Berg, Proc. Kon. Ned. Akad. Wetensch. C 91(4): 358 (1988). Pachytrophe obovata Bureau, Prodr. [A.P. de Candolle] 17: 235 (1873). Plecospermum bureaui A.G. Richt., Term. Füzetek 18: 296 (1895), nomen nudum et superfl., pro. syn. nom. ined. "Plecospermum obovatum Bureau" (Boivin 1717, P). Plecospermum (?) laurifolium Baill. in Grandidier, Hist. Madag. Vol. 35, Hist. Nat. Pl., Tome 5, Atlas 3, 2e partie: pl. 294a (1895) - Pachytrophe obovata var. laurifolia (Baill.) Léandri, Mém. Inst. Sci. Madag., ser. B, 1: 16 (1948). Pachytrophe obovata var. montana Léandri, Mém. Inst. Sci. Madag., ser. B, 1: 16 (1948).

Bagassa Aubl., Pl. Guiane. Suppl. 15 (1775).

Dioecious trees. Leaves opposite and decussate, lamina triplinerved, 3-lobed to entire. Stipules free, lateral. Inflorescences solitary or paired in the leaf axils, bracteate. Staminate inflorescences spicate with an abaxial sterile groove, to $12 \mathrm{~cm}$ long, flowers in longitudinal rows with, tepals 4, stamens 2 , straight in bud, pistillode present. Pistillate inflorescences globose-capitate, ca. 1-1.5 cm across, flowers 4-lobed to 4-parted, stigmas 2, filiform. Infructescences globose, ca. $2.5-3.5 \mathrm{~cm}$ across, green, tepals fleshy, yellowish to greenish, 
GARDNER ET AL., PHYLOGENOMICS AND GENERIC REVISION OF MOREAE

835 drupes ca. 7-8 mm long. Seeds ca. $3 \times 2 \mathrm{~mm}$, testa thin and not vascularized, cotyledons

836 equal.

837

838 Species and distribution: One, in tropical South America.

1. Bagassa guianensis Aubl., Pl. Guiane. Supple. 15 (1775)

\section{Maillardia}

Maillardia Frapp. ex Duch. in Maillard, Notes sur l'île de la Réunion, Annex P. 3 (1862)

Dioecious trees or shrubs. Leaves distichous, pinnately veined. Stipules free, semistamens 4, inflexed in bud, pistillode present. Pistillate inflorescences up to three together, uni- or bi-florous, perianth tubular 4-lobed, ovary adnate to the perianth, stigmas 2, equal.

$85418 \mathrm{~mm}$ long. Seeds to $13 \mathrm{~mm}$ long, testa thin, with a thickened vascularized part below the

855 hilum, cotyledons unequal.

856

857 Species and distribution: Two species, in Madagascar, Comoros, and the Seychelles.

860 borbonica (Duch.) C.C.Berg, Proc. Kon. Ned. Akad. Wetensch. C 91(4): 355 (1988) 
GARDNER ET AL., PHYLOGENOMICS AND GENERIC REVISION OF MOREAE

2. Maillardia montana Leandri, Mém. Inst. Sci. Madagascar, Sér. B, Biol. Vég. 1: 25 (1948) - Trophis montana (Leandri) C.C.Berg, Proc. Kon. Ned. Akad. Wetensch. C 91(4): 355 (1988).

Maillardia occidentalis Leandri, Mém. Inst. Sci. Madagascar, Sér. B, Biol. Vég. 1: 26 (1948)

Maillardia orientalis Léandri, Mém. Inst. Sci. Madagascar, Sér. B, Biol. Vég. 1: 27 (1948)

Maillardia mandrarensis Léandri, Mém. Inst. Sci. Madagascar, Sér. B, Biol. Vég. 1: 28 (1948).

Maillardia pendula Fosberg, Kew Bull. 29: 266, t. 2 (1974).

Milicia Sim, For. Fl. Port. E. Afr. 97 (1909).

Dioecious trees. Leaves distichous, lamina pinnately veined. Stipules free, not fully amplexicaul. Inflorescences spicate, usually solitary in the leaf axils or on leafless nodes, spicate, flowers in longitudinal rows alternating with rows of bracts, bracts mostly basally attached, abaxial sterile groove present. Staminate inflorescences to $20 \mathrm{~cm}$ long, flowers 4parted, imbricate, stamens 4, inflexed in bud, pistillode present. Pistillate inflorescences to $4.5 \mathrm{~cm}$ long, flowers 4-parted, decussate-imbricate, ovary free, stigmas 2, unequal.

Infructescences with enlarged fleshy perianths, surrounding slightly flattened drupaceous fruits, the latter to ca. $3 \mathrm{~mm}$ long. Seeds ca. $2 \mathrm{~mm}$ long, testa thin with a slightly thickened vascularized part below the hilum, cotyledons equal.

Species and distribution: Two species in tropical Africa.

1. Milicia excelsa (Welw.) C.C. Berg, Bull. Jard. Bot. Natl. Belg. 52(1-2): 227 (1982) Morus excelsa Welw., Trans. Linn. Soc. Lond. (Bot.) 27: 69, t. 23 (1869) - Maclura 
GARDNER ET AL., PHYLOGENOMICS AND GENERIC REVISION OF MOREAE

excelsa (Welw.) Bur. In DC., Prodr. 17: 231 (1873) - Chlorophora excelsa (Welw.)

Benth. \& Hook., Gen. Pl. 3(1): 363 (1880).

Chlorophora tenuifolia Engl., Bot. Jahrb. 20: 139 (1894).

Milicia africana Sim, For. Fl. Port. E. Afr. 97, t. 122 (1909).

Chlorophora alba A. Chev., Bull. Soc. Bot. Fr. 58 (Mém. 8d): 209 (1912).

2. Milicia regia (A. Chev.) C.C. Berg, Bull. Jard. Bot. Natl. Belg. 52(1-2): 227 (1982) Chlorophora regia A. Chev., Bull. Soc. Bot. Fr. 58 (Mém. 8d): 209 (1912) - Maclura regia (A. Chev.) Corner, Gard. Bull. Singapore 19: 237 (1962).

Morus L., Sp. P1. 986 (1753).

\section{Morus}

Dioecious trees or shrubs. Leaves trinerved (to five-nerved) at the base. Stipules free, nearly lateral. Inflorescences solitary or paired in the leaf axils, without an obvious sterile groove, interfloral bracts absent. Staminate inflorescences spicate or racemose, to $8 \mathrm{~cm}$ long, flowers 4-parted, imbricate, stamens 4, inflexed in bud, pistillode present. Pistillate inflorescences subcapitate to spicate, up to $16 \mathrm{~cm}$ long, flowers tepals 4, separate, decussate-imbricate, ovary free, stigmas 2, equal. Infructescences with enlarged fleshy perianths enclosing achene-like fruits, the latter ca. $1 \mathrm{~mm}$ long. Seeds less than $1 \mathrm{~mm}$ long, cotyledons equal.

Species and distribution: Sixteen species, Asia and North to Central America; introduced worldwide.

1. Morus alba L., Sp. Pl. 2: 986 (1753). var. alba

var. multicaulis (Perrottet) Loudon, Arbor. Frutic. Brit. 3: 1348 (1838).

2. Morus australis Poir. in Desrousseaux et al., Encycl. 4: 380 (1797). 
GARDNER ET AL., PHYLOGENOMICS AND GENERIC REVISION OF MOREAE

924 3. Morus boninensis Koidz., Bot. Mag. (Tokyo) 31: 38 (1917)

925 4. Morus cathayana Hemsl., J. Linn. Soc., Bot. 26: 456 (1894)

$926 \quad$ var. cathayana

927 var. gongshanensis (Z. Y. Cao) Z. Y. Cao, Acta Bot. Yunnan. 17: 154 (1995).

928 5. Morus celtidifolia Kunth, Nov. Gen. Sp. [H.B.K.] 2: 33 (1817).

929 6. Morus liboensis S. S. Chang, Acta Phytotax. Sin. 22: 66 (1984).

930 7. Morus macroura Miq., Pl. Jungh. 1: 42 (1851).

var. macroura

932

var. laxiflora G.K.Upadhyay \& A.A.Ansari, Rheedea 20: 44 (2010).

8. Morus koordersiana J.-F.Leroy, Bull. Mus. Natl. Hist. Nat. sér. 2, 21: 729 (1949) (endemic to Sumatra and possibly synonymous with $M$. macroura. However, it was not cited by Berg et al. (2006) either as a good species or as a synonym of the latter).

9. Morus microphylla Buckley, Acad. Nat. Sci. Philadelphia 1862: 8 (1863) (recognized in the Flora of North America (Flora of North America Editorial Committee, 1993) but likely conspecific with M. celtidifolia and considered so by Berg (2001)).

940 11. Morus nigra L. Sp. Pl. 2: 986 (1753).

941 12. Morus notabilis C. K. Schneid. in Sargent, Pl. Wilson. 3: 293 (1916).

942 13. Morus rubra L., Sp. Pl. 986 (1753).

$943 \quad$ var. rubra

var. murrayana (Saar \& Galla) Saar, Phytologia 91: 106 (2009).

945 14. Morus serrata Roxb., Fl. Ind., ed. 1832, 3: 596 (1832).

946 15. Morus trilobata (S. S. Chang) Z. Y. Cao, Acta Phytotax. Sin. 29: 265 (1991).

16. Morus wittiorum Hand.-Mazz., Anz. Akad. Wiss. Wien, Math.-Naturwiss. K1. 58: 88 (1921)

953 Paratrophis Blume, Ann. Mus. Bot. Lugduno-Batavi 2 (1856) 81. 
GARDNER ET AL., PHYLOGENOMICS AND GENERIC REVISION OF MOREAE

Pseudomorus Bureau, Ann. Sci. Nat., Bot. sér. 5, 11: 371 (1869).

Uromorus Bureau in A.DC., Prodr. 17: 236 (1873).

Calpidochlamys Diels, Bot. Jahrb. Syst. 67: 172 (1935); — Trophis sect. Calpidochlamys Corner, Gard. Bull. Singapore 19: 230 (1962).

Chevalierodendron J.-F. Leroy, Compt. Rend. Hebd. Séances Acad. Sci. 227: 146 (1948) .

Streblus Lour. sect. Paratrophis (Blume) Corner, Gard. Bull. Singapore 19: 216 (1962).

Streblus Lour. sect. Protostreblus Corner, Blumea 18: 393 (1970).

Morus L. subg. Gomphomorus J.-F. Leroy, Bull. Mus. Hist. Nat. (Paris), Sér. 2, 21: $732(1949)$

Dioecious trees or shrubs. Leaves distichous (or spiral in P. ascendens), pinnately veined, sometimes trinerved at the base. Stipules free, lateral. Inflorescences axillary, solitary or up to 5 together, spicate, with an abaxial sterile groove, interfloral bracts mostly peltate, flowers sessile in longitudinal rows, tepals 4, valvate, ciliolate. Staminate inflorescences up to at least $20 \mathrm{~cm}$. long, flowers with filaments inflexed in bud, pistillode present. Pistillate inflorescences up to at least $10 \mathrm{~cm}$ long, flowers usually at least 2 (to many), tepals free (except in P. philippinensis), stigma bifid, arms equal. Fruits drupaceous, red to black, with tepals persistent but usually not enlarged or fleshy (except in $P$. philippinensis and $P$. insignis), up to ca. $1 \mathrm{~cm}$ long. Seeds up to ca. 8 x $6 \mathrm{~mm}$, cotyledons equal.

Species and distribution: Twelve species from the Malesian region to Australia, New Zealand, and Oceania, Central and western South America.

1. Paratrophis anthropophagorum (Seem.) Benth. \& Hook. f. ex Drake, Ill. Fl. Ins. Pacif. 2961892

Trophis anthropophagorum Seem. [Bonplandia 9 (17-18): 259 (1861), nomen nudum] Fl. Vit. 258, t. 68 (1868); - Uromorus anthropophagorum (Seem.) Bureau in de 
GARDNER ET AL., PHYLOGENOMICS AND GENERIC REVISION OF MOREAE

983

984

985

986

987

988

989

990

991

992

993

994

995

996

997

998

999

1000

1001

1002

1003

1004

1005

1006

1007

1008

1009

1010

1011

Candolle, Prodr. 17 (1873) 236; — Streblus anthropophagorum (Seem.) Corner, Gard. Bull. Sing.19 (1962) 221.

Caturus oblongatus Seem., Fl. Vit. 254 (1868).

Paratrophis ostermeyri Rech., Fedd. Rep. 5: 130 (1908).

Paratrophis viridissima Rech., Fedd. Rep. 5: 130 (1908).

Paratrophis zahlbruckneri Rech., Fedd. Rep. 5: 130 (1908).

Pseudomorus brunoniana (Endl.) Bureau var. tahitensis J. Nadeaud, Énum. Pl. Tahiti 43 (1873) - Uromorus tahitensis (J. Nadeaud) Bureau in de Candolle, Prodr. 17: 237 (1873) - Paratrophis tahitensis (Bureau) Benth. \& Hook.f. ex Drake, Ill. Ins. Mar. Pacif. Fasc. 7: 296 (1892); et Fl. Polyn. Franc. 193 (1892). - Streblus tahitensis (J. Nadeaud) E.J.H. Corner, Gard. Bull. Singapore 19: 225 (1962).

2. Paratrophis ascendens (Corner) E.M. Gardner comb. nov. — based on Streblus ascendens Corner, Blumea 18: 395, t.1 (1970).

3. Paratrophis australiana C.T. White, Contr. Arnold Arbor. 4: 15 (1933) - Streblus glaber (Merr.) Corner var. australianus (C.T. White) Corner, Gard. Bull. Singapore 19: 221 (1962) — Streblus glaber (Merr.) Corner subsp. australianus (C.T. White) C.C. Berg, Blumea 50: 548 (2005).

4. Paratrophis banksii Cheeseman, Man. N.Z. Fl. 633 (1906) - Streblus banksii (Cheeseman) C.J. Webb, in Connor \& Edgar, New Zealand J. of Bot. 25136 (1987). Paratrophis heterophylla var. elliptica Kirk T.N.Z.L 29: 500, t. 46 (1897); — Streblus heterophyllus var. ellipticus (Kirk) Corner, Gard. Bull. Singapore 19: 222 (1962). Note:- Morphologically very close to and not always distinguishable from $P$. microphylla.

5. Paratrophis glabra (Merr.) Steenis, J. Bot. 72: 8 (1934) - Gironniera glabra Merr., Philipp. J. Sci., 1, Suppl. 42 (1906); Enum. Philipp. Flow. Pl. 2: 35 (1923) — 
GARDNER ET AL., PHYLOGENOMICS AND GENERIC REVISION OF MOREAE

1012 Chevalierodendron glabrum (Merr.) J.-F. Leroy, Compt. Rend. Hebd. Séances Acad. Sci.

1013 227: 146 (1948) — Streblus glaber (Merr.) Corner, Gard. Bull. Singapore 19: 221 (1962).

1014 Aphananthe negrosensis Elmer, Leafl. Philipp. Bot. 2: 575 (1909).

1015 Pseudostreblus caudatus Ridl., J. Fed. Malay States Mus. 6: 54 (1915).

1016 Streblus laevifolius Diels, Bot. Jahrb. Syst. 67: 171 (1935).

1017 Streblus urophyllus Diels, Bot. Jahrb. Syst. 67: 172 (1935) — Streblus glaber (Merr.)

1018 Corner subsp. urophyllus (Diels) C.C. Berg, Blumea 50: 548 (2005);

1019 Streblus urophyllus Diels var. salicifolius Corner, Gard. Bull. Singapore. 19: 225 (1962).

1020

1021 Note: Berg et al. (2006) treated P. australiana and Streblus urophyllus as subspecies of

1022 Streblus glaber. Paratrophis australiana, endemic to Australia, has crenate leaf margins

1023 and somewhat larger staminate inflorescences with more interfloral bracts than P. glabra;

1024 these morphological differences are consistent and geographically confined, and we

1025 therefore reinstate $P$. australiana. This stands in contrast to Streblus urophyllus, which we

1026 provisionally maintain in synonomy under P. glabra. Although collections from Mt.

1027 Wilhelm in New Guinea are remarkable for their thick coriaceous leaves and spinose

1028 margins, similar toothed margins can be found at higher elevations in Borneo and Sulawesi,

1029 suggesting that the striking leaf morphology of $S$. urophyllus is an alpine effect not

1030 indicative of speciation. We reserve judgment on the status of Streblus urophyllus var.

1031 salicifolius Corner, applied by Corner (1962) to specimens with linear leaves, provisionally

1032 maintaining it in synonomy following Berg et al. (2006).

1033

1034

6. Paratrophis insignis (Bureau) E.M. Gardner comb. nov. — based on Morus insignis

1035 Bureau, in De Candolle, Prodr. 17: 247 (1873).

1036 Morus peruviana Planch. ex Koidz., Fl. Symb. Orient.-Asiat. 88 (1930).

1037 Morus trianae J.-F.Leroy, Bull. Mus. Hist. Nat. (Paris) Sér. 2, 21: 731 (1949).

$1038 \quad$ Morus marmolii Legname, Lilloa 33: 334 (1973)

1039 Note: The infructescences differ from most other Paratrophis in their fleshy free tepals and

1040 denser aggregation of flowers, but the staminate inflorescences are typical of the genus. 
GARDNER ET AL., PHYLOGENOMICS AND GENERIC REVISION OF MOREAE

7. Paratrophis microphylla (Raoul) Cockayne, Bot. Notes Kennedy's Bush \& Scenic Res. Port Hills, Lyttelton (Rep. Scenery Preserv.) 3 (1915) - Epicarpurus microphyllus Raoul, Choix Pl. Nouv.-Zel. 14. (1846) - Taxotrophis microphylla (Raoul) F. Muell., Fragm. (Mueller) 6(47): 193 (1868).

Paratrophis heterophylla Blume, Mus. Bot. 2(1-8): 81. (1856).

\section{Paratrophis pendulina (Endl.) E.M. Gardner, comb. nov. — based on Morus} pendulina Endl., Prodromus Florae Norfolkicae 40 (1833) - Pseudomorus pendulina (Endl.) Stearn, J. Arnold Arbor. 28: 427 (1947) - Pseudomorus brunoniana var. pendulina (Endl.) Bureau, Ann. Sci. Nat. Bot. sér. 5, 11: 372 (1869) - Streblus pendulinus (Endl.) F. Muell., Fragmenta Phytographiae Australiae (1868). Morus brunoniana Endl., Atakta Bot. t. 32 (1835) - Streblus brunonianus (Endl.) F. Muell., Fragm. Phyt. Australiae 6: 192 (1868) - Pseudomorus brunoniana (Endl.) Bureau, Ann. Sci. Nat., Bot. sér. 5, 11: 372 (1869) Pseudomorus brunoniana var. australiana Bureau, Ann. Sci. Nat., Bot. sér. 5, 11: 373 (1869) - Pseudomorus pendulina var. australiana (Bureau) Stearn, J. Arnold Arbor. 28: 427 (1947).

Pseudomorus brunoniana var. australiana subvar. castaneaefolia Bureau, Ann. Sci. Nat., Bot. sér. 5, 11: 372 (1869). Pseudomorus brunoniana var. obtusa Bureau, Ann. Sci. Nat., Bot. sér. 5, 11: 373 (1869) - Pseudomorus pendulina var. obtusa (Bureau) Stearn, J. Arnold Arbor. 28: 428 (1947), as var. obtusata.

Pseudomorus sandwicensis O. Deg., Fl. Hawaiiensis fam. 38 (1938) - Pseudomorus brunoniana var. sandwicensis (O. Deg.) Skottsb., Acta Horti Gothob. 15: 347 (1944) - Pseuomorus pendulina var. sandwicensis (O. Degener) Stearn, J. Arnold Arbor. 28: 428 (1947) - Streblus sandwicensis (O. Deg.) H. St. John, Pacific Trop. Bot. Gard. Mem. 1: 374. 1973.

Note: This complex requires further investigation. Although the types of Morus pendulina, Morus brunoniana, Pseudomorus sandwicensis, and Pseudomorus brunoniana var. obtusa differ from one another, it is difficult to discern clear geographic patterns that warrant 
GARDNER ET AL., PHYLOGENOMICS AND GENERIC REVISION OF MOREAE

1072 maintaining separate species, and we therefore provisionally treat them all as one

1073 widespread and variable species.

1074

1075 9. Paratrophis philippinensis (Bureau) Fern.-Vill., Nov. App. 98 (1880) - Uromorus

1076 philippinensis Bureau in A.DC., Prodr. 17: 237 (1873) — Trophis philippinensis (Bureau)

1077 Corner, Gard. Bull. Singapore 19: 231 (1962).

1078 Sloetia minahassae Koord., Versl. Minahasa 645 (1898).

1079 Paratrophis grandifolia Elmer, Leafl. Philipp. Bot. 5: 1814 (1913).

1080 Calpidochlamys branderhorstii Diels, Bot. Jahrb. Syst. 67: 173 (1935) — Trophis

1081 branderhorstii (Diels) Corner, Gard. Bull. Singapore 19: 231 (1962).

1082 Calpidochlamys drupacea Diels, Bot. Jahrb. Syst. 67: 173 (1935) — Trophis drupacea

1083 (Diels) Corner, Gard. Bull. Singapore 19: 231 (1962).

1084 Note: This species is the only Paratrophis with fused tepals and one of only two whose

1085 tepals develop into a fleshy accessory fruit. The staminate inflorescences, however, are

1086 typical of the genus.

10. Paratrophis sclerophylla (Corner) E.M. Gardner, comb. nov. — based on Streblus sclerophyllus Corner, Blumea 18: 399 (1970).

11. Paratrophis smithii Cheeseman T.N.Z.L 20:148 (1888) - Streblus smithii (Cheeseman) Corner Gard. Bull. Singapore 19: 224 (1962).

1093 Note: Morphologically very close to P. anthropophagorum.

12. Paratrophis solomonensis (Corner) E.M. Gardner, comb. nov. — based on Streblus solomonensis Corner, Gard. Bull. Singapore 19: 224 (1962).

1097 Note:- Morphologically very close to P. anthropophagorum. 
GARDNER ET AL., PHYLOGENOMICS AND GENERIC REVISION OF MOREAE

1102 Sorocea A. St-Hil., Mém. Mus. Hist. Nat. 7: 473 (1821).

1103 Balanostreblus Kurz, J. Asiat. Soc. Bengal., Pt. 2, Nat. Hist., 42: 247 (1873), p.p.

1104 Pseudosorocea Baill., Hist. Pl. 6: 210 (1875).

1105 Trophisomia Rojas Acosta, Bull. Acad. Inst. Geogr. Bot. 24: 211 (1914).

1106 Paraclarisia Ducke, Arq. Serv. Florest. 1(1): 2 (1939).

1108 Dioecious trees. Leaves alternate, distichous, lamina pinnately veined, 3-lobed to entire.

1109 Stipules free, lateral. Inflorescences solitary or paired in the leaf axils or below the leaves,

1110 racemose to spicate to subcapitate or uniflorous, bracts basally attached to peltate.

1111 Staminate flowers 4-lobed to 4-parted, tepals decussate-imbricate, stamens (3-)4, straight

1112 in bud, pistillode usually absent. Pistillate flowers tubular, 4-lobed to sub-entire, ovary

1113 basally adnate to the perianth, stigmas 2, short, usually tongue-shaped. Infructescences

1114 with drupaceous fruits enclosed by fleshy enlarged perianths, the latter red to orange,

1115 turning black at maturity. Seeds large, testa thin, embryo green, cotyledons very unequal,

1116 the smaller one minute and enclosed by the larger.

1118 Species and distribution: 19 species in Central and South America from Mexico to

1119 Argentina.

1121 Note: This species list follows the Flora Neotropica monograph (Berg 2001) with the

1122 addition of four new species and one status change published later. Names synonymized by

1123 Berg (2001) but recognized by Burger et al. (1962) are noted in parentheses. Complete

1124 synonymies can be found in those treatments.

Sorocea subg. Sorocea

1127 Sorocea affinis Hemsl., Biol. Cent.-Amer., Bot. 3: 150 (1883).

1128 Sorocea angustifolia Al.Santos \& Romaniuc, Novon 24: 199 (2015).

1129 Sorocea bonplandii (Baill.) W.C. Burger, Lanj. \& de Boer, Acta Bot. Neerl. 11: 465

1130 (1962). 
GARDNER ET AL., PHYLOGENOMICS AND GENERIC REVISION OF MOREAE

Sorocea briquetii J.F.Macbr., Publ. Field Columb. Mus., Bot. Ser. 11: 16 (1931) (incl. S. pileate W.C. Burger). Sorocea carautana M.D.M.Vianna, Carrijo \& Romaniuc, Novon 19: 549 (2009). Sorocea ganevii R.M.Castro, Neodiversity 1: 18 (2006).

Sorocea guilleminiana Gaudich., Voy. Bonite, Bot. 3: t. 74 (1843) (incl. S. klotzschiana Baill. and S. macrogyna Lanj. \& Wess. Boer).

Sorocea hilarii Gaudich., Voy. Bonite, Bot. 3: t. 71 (1843) (incl. S. racemosa Gaudich.).

Sorocea jaramilloi C.C.Berg, Novon 6: 241 (1996).

Sorocea longipedicellata A.F.P. Machado, M.D.M. Vianna \& Romaniuc, Syst. Bot. 38: 687 (2013).

Sorocea muriculata Miq., C.F.P. von Martius \& auct. suc. (eds.), Fl. Bras. 4(1): 113 (1853).

subsp. muriculata (incl. S. amazonica Miq.)

subsp. uaupensis (Baill.) C.C. Berg, Proc. Kon. Ned. Akad. Wetensch. C 88: 387 (1985) (incl. S. guayanensis W.C. Burger).

Sorocea pubivena Hemsl., Biol. Cent.-Amer., Bot. 3: 150 (1883).

subsp. pubivena (incl. S. cufodontii W.C. Burger)

subsp. hirtella (Mildbr.) C.C. Berg, Novon 6: 243 (1996) (incl. S. opima J.F.

Macbr.)

subsp. oligotricha (Akkermans \& C.C. Berg) C.C. Berg, Novon 6: 243 (1996).

Sorocea ruminata C.C.Berg, Novon 6: 244 (1996).

Sorocea sarcocarpa Lanj. \& Wess. Boer, Acta Bot. Neerl. 11: 452 (1962).

Sorocea steinbachii C.C. Berg, Proc. Kon. Ned. Akad. Wetensch. C 88: 385 (1985).

Sorocea trophoides W.C. Burger, Acta Bot. Neerl. 11: 450 (1962).

Sorocea subg. Paraclarisia (Ducke) W.C. Burger, Lanj. \& Wess. Boer, Acta Bot. Neerl. 11: 468 (1962).

Sorocea duckei W.C.Burger, Acta Bot. Neerl. 11: 473 (1962). 
GARDNER ET AL., PHYLOGENOMICS AND GENERIC REVISION OF MOREAE

Sorocea sprucei (Baill.) J.F.Macbr., Publ. Field Mus. Nat. Hist., Bot. Ser. 11: 16 (1931).

subsp. sprucei (incl. S. arnoldoi Lanj. \& Wess. Boer). subsp. saxicola (Hassl.) C.C.Berg, Proc. Kon. Ned. Akad. Wetensch., Ser. C., Biol. Med. Sci. 88: 391 (1985).

Sorocea subumbellata (C.C. Berg) Cornejo, Novon 19: 297 (2009).

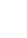

\section{Taxotrophis}

Taxotrophis Blume, Ann. Mus. Bot. Lugduno-Batavi 277 (1856); Hutch., Bull. Misc. Inform. Kew 147 (1918).

Streblus Lour. sect. Taxotrophis (Blume) Corner, Gard. Bull. Singapore 19: 218 (1962); Berg et al., Fl. Males. Ser. 1, Vol. 17, Pt. 2 (2006).

Monoecious or dioecious trees or shrubs, usually with lateral or terminal thorns. Leaves distichous, pinnately veined, petioles adaxially pubescent. Stipules free, lateral.

Inflorescences axillary, solitary or paired, with an abaxial sterile groove, interfloral bracts basally attached, flowers with 4 free tepals, valvate. Staminate inflorescences spicate to sub-capitate, flowers with filaments inflexed in bud, pistillode present. Pistillate inflorescences uniflorous or sub-spicate, flowers usually pedicellate, stigma bifid, arms equal. Fruits drupaceous, up to ca. $1 \mathrm{~cm}$ long, usually loosely enclosed by the enlarged persistent tepals. Seeds up to ca. 8 × $6 \mathrm{~mm}$, cotyledons subequal to unequal.

Species and distribution: Six species, ranging from Sri Lanka to New Guinea.

1. Taxotrophis ilicifolia (Kurz) S.Vidal, Revis. Pl. Vasc. Filip. 249 (1886) Balanostreblus ilicifolia Kurz, J. Asiat. Soc. Bengal, Pt. 2, Nat. Hist. 42(4): 248 (1874) - Streblus ilicifolius (Kurz) Corner, Gard. Bull. Singapore 19: 227 (1962). Pseudotrophis laxiflora Warb., Bot. Jahrb. Syst. 13294 (1891). Taxotrophis obtusa Elmer, Leafl. Philipp. Bot. 51813 (1913). 
GARDNER ET AL., PHYLOGENOMICS AND GENERIC REVISION OF MOREAE

Taxotrophis laxiflora Hutch., Bull. Misc. Inform. Kew 151 (1918). - Streblus

laxiflorus (Hutch.) Corner, Gard. Bull. Singapore 19229 (1962).

Taxotrophis triapiculata Gamble, Bull. Misc. Inform. Kew 188 (1913).

Taxotrophis eberhardtii Gagnep., Fl. Indo-Chine 5700 (1928).

Taxotrophis macrophylla auct. non Boerl.: Burkill, Dict. Econ. Prod. Malay Penins. $2126(1935)$.

2. Taxotrophis macrophylla (Blume) Boerl., Handl. Fl. Ned. Ind. 3: 359 (1900).

Streblus macrophyllus Blume, Ann. Mus. Bot. Lugduno-Batavi 2: 80 (1856) —

Diplocos? macrophyllus (Blume) Bureau in A.DC., Prodr. 17: 216 (1873).

Pseudotrophis mindanaensis Warb. in Perkins, Fragm. Fl. Philipp. 1: 165 (1905);

Elmer, Leafl. Philipp. Bot. 5: 1815 (1913), 'Taxatrophis mindanaensis' in nota. Paratrophis caudata Merr., Philipp. J. Sci., 1, Suppl. 183 (1906).

Taxotrophis balansae Hutch., Bull. Misc. Inform. Kew 151 (1918).

Dimerocarpus brenieri Gagnep., Bull. Mus. Hist. Nat. (Paris) 27: 441 (1921).

3. Taxotrophis perakensis (Corner) E.M. Gardner, comb. nov., based on Streblus perakensis Corner, Gard. Bull. Singapore 19: 223 (1962).

Note: Although Corner (1962) considered S. perakensis species part of section Paratrophis, albeit with some hesitation, Berg et al. (2006), whom we follow, placed it in Taxotrophis based on the spines that appear on some specimens. This is a rather variable species that requires further investigation to properly elucidate its limits and affinities.

4. Taxotrophis spinosa Steenis in Backer \& Bakh.f., Fl. Java 2 (1965) 16.

Urtica spinosa Blume, Bijdr. (1825) 507. — Streblus spinosus (Blume) Corner, Gard. Bull. Singapore 19: 229 (1962).

Taxotrophis javanica Blume, Ann. Mus. Bot. Lugduno-Batavi 2: 77, t. 26 (1856).

5. Taxotrophis taxoides (B. Heyne ex Roth) W.L. Chew ex E.M. Gardner, comb. nov. 
GARDNER ET AL., PHYLOGENOMICS AND GENERIC REVISION OF MOREAE

Trophis taxoides B. Heyne ex Roth, Nov. Pl. Sp. 368 (1821). — Trophis taxiformis Spreng., Syst. Veg. 3902 (1826), nom. nov. illeg. — Streblus taxoides (B. Heyne ex Roth) Kurz, Forest Fl. Burma 2: 465 (1877) — Phyllochlamys taxoides (B. Heyne ex Roth) Koord., Exkurs.-Fl. Java 2: 89 (1912).

Trophis spinosa Roxb., Fl. Ind., ed. Carey 3: 762 (1832), non Willd. 1806, nec Blume 1826. - Epicarpurus spinosus (Roxb.) Wight, Icon. Pl. Ind. Orient. 6: 7, t. 1962 (1853), p.p. - Phyllochlamys spinosa (Roxb.) Bureau in A.DC., Prodr. 17: 218 (1873);

Epicarpurus timorensis Decne., Nouv. Ann. Mus. Hist. Nat. 3: 499, t. 21 (1834).

Taxotrophis roxburghii Blume, Ann. Mus. Bot. Lugduno-Batavi 2: 78 (1856)

Streblus microphyllus Kurz, Prelim. Rep. Forest Pegu App. A, cxviii; App. B, 84 (1875); - Streblus taxoides (B. Heyne ex Roth) Kurz var. microphylla (Kurz) Kurz, Forest Fl. Burma 2: 465 (1877).

Phyllochlamys wallichii King ex Hook.f., Fl. Brit. India 5: 489 (1888);

Phyllochlamys taxoides (B. Heyne ex Roth) Koord. var. parvifolia Merr., Enum.

Philipp. Flow. Pl. 2: 38 (1923).

Taxotrophis poilanei Gagnep., Fl. Indo-Chine 5: 701 (1928).

Taxotrophis crenata Gagnep., Fl. Indo-chine 5: 702, t. 82 (1928). - Streblus crenatus (Gagnep.) Corner, Gard. Bull. Singapore 19: 226 (1962).

Phyllochlamys tridentata Gagnep., Fl. Indo-Chine 5: 714 (1928).

Note: In the 1950s, Dr. Chew Wee Lek annotated quite a lot of specimens at K and SING with the new combination Taxotrophis taxoides. However, the combination was never published, probably because the need for the combination was obviated in 1962 when Corner, his doctoral supervisor, reduced Taxotrophis to a section of Streblus.

6. Taxotrophis zeylanica (Thwaites) Thwaites, Enum. P1. Zeyl. [Thwaites] 264 (1861). Epicarpurus zeylanicus Thwaites, Hooker's J. Bot. Kew Gard. Misc. 4: 1 (1852) Diplocos zeylanica (Thwaites) Bureau, Prodr. [A. P. de Candolle] 17: 215 (1873) — Streblus zeylanicus (Thwaites) Kurz, Forest Fl. Burma 2: 464 (1877). 
GARDNER ET AL., PHYLOGENOMICS AND GENERIC REVISION OF MOREAE

Taxotrophis caudata Hutchinson, Bull. Misc. Inform. Kew 1918(4): 149 (1918).

\section{Trophis}

Trophis Lour., P. Browne, Civ. Nat. Hist. Jamaica 357 (1756), nom. cons.

1259 Dioecious trees or shrubs. Leaves distichous, pinnately veined. Stipules free, lateral.

1260 Inflorescences axillary or just below the leaves, solitary or paired, interfloral bracts basally

1261 attached. Staminate inflorescences spicate to racemose with an abaxial sterile groove, tepals

1262 4, basally connate, stamens 4, filaments inflexed in bud, pistillode present. Pistillate

1263 inflorescences spicate to racemose or subcapitate, tepals 4, connate, forming a tubular

1264 perianth, ovary adnate to the perianth or not, stigma bifid, arms equal. Fruits drupaceous,

1265 up to ca. $1.5 \mathrm{~cm}$ long, adnate to the perianth or not, the perianth enlarged and fleshy or not.

1266 Seeds up to ca. $1 \mathrm{~cm}$ long, cotyledons equal.

1268 Species and distribution: Five species in the neotropics.

Trophis P. Browne sect. Trophis

1272 1. Trophis cuspidata Lundell, Amer. Midl. Naturalist 19: 427 (1938).

1273 2. Trophis mexicana (Liebm.) Bureau, Prodr. [A. P. de Candolle] 17: 253 (1873).

1274 3. Trophis noraminervae Cuevas \& Carvajal, Acta Bot. Mex. 47: 2 (1-7, fig.) (1999).

1275 4. Trophis racemosa Urb., Symb. Antill. (Urban). 4(2): 195 (1905).

1277 Trophis P. Browne sect. Echinocarpa C.C. Berg, Proc. Kon. Ned. Akad. Wetensch., Ser. C, 1278 Biol. Med. Sci. 91: 353 (1988). 
GARDNER ET AL., PHYLOGENOMICS AND GENERIC REVISION OF MOREAE

1280 5. Trophis involucrata W.C. Burger, Phytologia 26: 432 (1973).

Olmedieae Trécul, Ann. Sci. Nat., Bot. sér. 3, 8 (1847) 126

Strebleae Bureau in DC., Prodr. 17: 215 (1873), p.p.

Tree or shrubs, monoecious or dioecious (or androdioecious), mostly with self-pruning branches. Leaves alternate or opposite, distichous or spirally arranged; stipules lateral to amplexicaul. Inflorescences mostly unisexual, capitate, mostly discoid to urceolate,

1292 involucrate, tepals mostly 4, connate or not. Staminate inflorescences usually many-

1293 flowered; stamens 4 or fewer, with filaments straight or less often inflexed in bud, pistillode 1294 mostly absent. Pistillate inflorescences one to many-flowered, ovary free or not, stigmas 2, 1295 filiform. Fruits mostly drupaceous, mostly enclosed by a fleshy perianth or embedded in a

1296 fleshy receptacle. Seeds with or without endosperm, testa thin, vascularized, cotyledons 1297 mostly equal.

Genera and distribution: 13 genera with 63 species. Eight neotropical genera: Castilla (3 spp.), Helicostylis (7), Maquira (4), Naucleopsis (22), Olmedia (1), Perebea (9), Antiaris (1); Antiaropsis (2) in New Guinea; Mesogyne (1) in Africa; Sparattosyce (1) in New Caledonia; and Streblus (3) in South to Southeast Asia.

\section{Olmedia}

1307 Olmedia Ruiz \& Pav., Syst. Veg. Fl. Peruv. Chil.1:257.1798. Type — Olmedia aspera Ruiz 1308 \& Pav. 
GARDNER ET AL., PHYLOGENOMICS AND GENERIC REVISION OF MOREAE

1312 Dioecious trees or shrubs. Leaves distichous, lamina pinnately veined. Stipules free, not 1313 fully amplexicaul. Inflorescences unisexual, with a well-developed involucre. Staminate

1314 inflorescences discoid, multiflorous; tepals 4, valvate, stamens 4, inflexed in bud, pistillode

1315 absent. Pistillate inflorescences usually uniflorous, perianth tubular, 4-dentate, ovary free, 1316 stigmas 2, equal. Fruits drupaceous, surrounded by fleshy persistent perianth and

1317 subtended by spreading, fleshy involucral bracts. Seeds ca. $5 \mathrm{~mm}$ long, cotyledons equal. 1318

1334 Streblus Lour., Fl. Cochinch. (1790) 615.

1335 Achymus Juss., Dict. Sci. Nat. 1, Suppl. 31 (1816) .

1336 Epicarpurus Blume, Bijdr. 488 (1825).

1337 Albrandia Gaudich. in Freyc., Voy. Uranie, Bot. 509 (1830).

1338 Calius Blanco, Fl. Filip. 698 (1837).

\section{Streblus}


GARDNER ET AL., PHYLOGENOMICS AND GENERIC REVISION OF MOREAE

1339 Teonongia Stapf, Hooker's Icon. P1. 30: t. 2947 (1911).

1340 Diplothorax Gagnep., Bull. Soc. Bot. France 7598 (1928).

1342 Trees or shrubs, dioecious or monoecious. Leaves distichous, lamina pinnately veined.

1343 Stipules free, lateral. Inflorescences bisexual or unisexual, capitate, with a rudimentary

1344 involucre, bracts basally attached. Staminate inflorescences discoid capitate, multiflorous;

1345 tepals 4, imbricate, stamens 4, inflexed in bud, pistillode present but small. Pistillate

1346 inflorescences usually uniflorous, tepals 4, ovary free, stigmas 2, equal. Fruits drupaceous,

1347 up to ca. $8 \mathrm{~mm}$ long, initially enclosed by enlarged but not fleshy tepals, which may open

1348 later. Seeds ca. $5 \mathrm{~mm}$ long, cotyledons equal or very unequal.

1350 Species and distribution: three species from India to South China and from mainland

1351 Southeast Asia to the Philippines and the Moluccas.

1352

1. Streblus asper (Retz.) Lour., Fl. Cochinch. 2: 615 (1790).

Trophis aspera Retz., Observ. Bot. 5 (1788) - Epicarpurus asper (Retz.) Steud.

Nomencl. Bot. ed. 2, 1: 556 (1840).

Trophis cochinchinensis Poir., Encycl. 8 (1808) 123.

Epicarpurus orientalis Blume, Bijdr. (1825) 488

Calius lactescens Blanco, Fl. Filip. (1837) 698; ed. 3, 3 (1879) 1103, t. 171 . -

Streblus lactescens (Blanco) Blume, Ann. Mus. Bot. Lugduno-Batavi 2 (1856) 80.

Note: Retzius's Trophis aspera predated Loureiro's Streblus asper by two years, making

1366 the latter an implied new combination under Article 41.1 of the Code (cf. Ex. 10).

1367 Synonymies of the $S$. asper have sometimes erroneously included Trophis aculeata Roth, 1368 which is actually Maclura spinosa (Roxb. ex Willd.) C.C. Berg. 
GARDNER ET AL., PHYLOGENOMICS AND GENERIC REVISION OF MOREAE

2. Streblus celebensis C.C. Berg, Blumea 50547 (2005).

3. Streblus tonkinensis (Eberh. \& Dubard) Corner, Gard. Bull. Singapore 19 (1962): 228.

Dorstenieae Gaudich. in Freyc., Voy. Uranie, Bot. (1830).

1381 Brosimeae Trécul, Ann. Sci. Nat., Bot. sér. 3, 8: 146 (1847).

1382 Fatoueae Engl., Nat. Pflanzenfam. 3, 1: 71 (1888).

1384 Tree, shrubs, lianas, and herbs, monoecious or less often dioecious. Leaves alternate or less

1385 commonly (sub)opposite, distichous or spirally arranged; stipules lateral to fully

1386 amplexicaul. Inflorescences unisexual or bisexual, cymose, spicate, globose, or discoid to

1387 turbinate or cup-shaped, multiflorous or uniflorous (the latter in pistillate inflorescences

1388 only), bracteate or not, interfloral bracts mostly peltate. Staminate flowers with tepals (1-

1389 )2-4 or absent, stamens 1-4 with filaments straight or inflexed in bud, pistillode present or

1390 (more often) absent. Pistillate flowers free or connate or embedded in the receptacle, tepals

$13912-4$, ovary free or not, stigmas 1 or 1, equal or unequal. Fruits drupaceous or drupe-like

1392 due to a persistent fleshy perianth and/or receptacle, the whole endocarp unit often

1393 ballistically ejected from the infructescence. Seeds with or without endosperm, large or

1394 small; cotyledons equal or unequal.

1396 Genera and distribution: eleven genera and 63 species with a worldwide distribution:

1397 Bleekrodea (Africa and Southeast Asia), Bosqueiopsis (Africa), Brosimum (Neotropics),

1398 Broussonetia (Asia to Oceania; introduced worldwide), Dorstenia (Africa and South 
GARDNER ET AL., PHYLOGENOMICS AND GENERIC REVISION OF MOREAE

1399 America, with one species in India), Fatoua (Madagascar and Japan to New Caledonia;

1400 introduced worldwide), Helianthostylis (Neotropics), Malaisia (Southeast Asia to New

1401 Caledonia), Scyphosyce (Africa), Sloetia (Southeast Asia), Sloetiopsis (Africa), Trilepisium

1402 (Africa), Trymatococcus (Neotropics), Utsetela (Africa).

\section{Sloetiopsis}

Sloetiopsis Engl., Bot. Jahrb. 39: 573 (1907).

$1408 \quad$ Neosloetiopsis Engl., Bot. Jahrb. 51: 426 (1914)

Streblus auct. non Lour., C.C. Berg, Proc. Kon. Ned. Acad. Wetensch. C. 91: 357. 1988.

1412 Tree or shrubs, dioecious (or monoecious). Leaves distichous, pinnately veined, cystoliths

1413 present; stipules free, nearly amplexicaul. Inflorescences unisexual (or bisexual); staminate

1414 inflorescences spicate with an abaxial sterile groove, bracts mostly peltate, tepals 4, free or

1415 basally connate filaments inflexed in bud, pistillode small; pistillate inflorescences

1416 uniflorous, bracts mostly basally attached, tepals 4, free, imbricate, 2 stigmas. Fruits

1417 drupaceous, fleshy endocarp dehiscent, tepals enlarged and persistent but not fleshy. Seeds

1418 globose, ca. $4 \mathrm{~mm}$, endocarp coriaceous with a hard disc against the hilum, testa

1419 vascularized with a thick apical cap, cotyledons equal.

1. Sloetiopsis usambarensis Engl., Bot. Jahrb. 39: 573 (1907) — Streblus usambarensis

1425 Note. The nearly amplexicaul stipules and occasional bisexual inflorescences reflect an 1426 affinity with the Southeast Asian Sloetia, also a member of the Dorstenieae. 
GARDNER ET AL., PHYLOGENOMICS AND GENERIC REVISION OF MOREAE

\section{Tribe PARARTOCARPEAE}

1431 Parartocarpeae N.J.C. Zerega \& E.M. Gardner Zerega, Phytotaxa 388, 253-265 (2019).

1432 Shrubs to large trees, monoecious or dioecious; abundant white exudate. Leaves distichous

1433 or spirally arranged; simple; entire; pinnately veined; thin to thick coriaceous; glabrous,

1434 pubescent, scabrid, or hispid pubescent. Stipules axillary, simple or paired, lateral.

1435 Inflorescences solitary or paired in leaf axils, unisexual (or bisexual with a single apical

1436 pistillate flower), uniflorous, cymose, or capitate with stamens or ovaries sunken into the

1437 receptacle; pedunculate; involucre of 3-8 triangular bracts, basally connate. Staminate

1438 inflorescences with numerous flowers, tepals 4-5, stamens 5 and normally positioned or 1-

14393 in cavities in the receptacle with the anthers exerted through perforations in the upper

1440 surface of the receptacle, filaments free or united. Pistillate inflorescences uniflorous or

1441 (sub)globose with ovaries solitary in each cavity, unilocular, the style apical with a short

1442 exerted stigma. Fruits drupaceous, enclosed by persistant tepals, or aggregated into

1443 syncarps formed by the enlargement of the entire inflorescence.

1445 Genera and distribution: Three genera and five species, from Southern China to the

1446 Solomon Islands: Hullettia, Parartocarpus, and Pseudostreblus.

\section{Pseudostreblus}

1451 Pseudostreblus Bureau, in A.P. de Candolle, Prodr. 17: 220 (1873).

1452 Streblus Lour. sect. Pseudostreblus (Bureau) Corner, Gard. Bull. Singapore 19: 217 (1962).

1454 Monoecious trees. Leaves distichous, pinnately veined. Stipules free, lateral.

1455 Inflorescences axillary. Staminate inflorescences cymose, tepals 5, imbricate, filaments

1456 inflexed in bud but apparently straightening gradually upon anthesis, pistillode minute,

1457 conical, pubescent, interfloral bracts few, basally attached. Pistillate inflorescences

1458 uniflorous, pedunculate, involucral bracts $3, \pm$ connate, tepals 4 , imbricate, stigma bifid, 
GARDNER ET AL., PHYLOGENOMICS AND GENERIC REVISION OF MOREAE

1459 arms equal. Fruits drupaceous, ca. $1 \mathrm{~cm}$ long, with tepals enlarged and loosely enclosing

1460 the fruit. Seeds ellipsoid, ca. 6 × $8 \mathrm{~mm}$, cotyledons unequal.

1461

1462 Species and distribution: One, in South to Southeast Asia and Southern China.

1464 Note: Pseudostreblus is remarkable for its five-parted staminate flowers.

1. Pseudostreblus indicus Bureau, in A.P. de Candolle, Prodr. 17: 220 (1873).

\section{Conclusion}

1471 The revisions presented here, based on the best phylogenetic evidence available to date,

1472 provide for seven monophyletic tribes of Moraceae and ten monophyletic genera within

1473 Moreae. We hope that the resulting taxonomic and phylogenetic framework will provide a

1474 solid foundation for further research into the systematics and evolution of Moraceae.

\section{Author contributions}

1478 EMG led the writing of the manuscript, did field, lab, and herbarium work, conducted all

1479 phylogenetic analyses, and was responsible for the taxonomic treatment. MG performed lab

1480 work for the Moraceae333 samples. RC, SD, NE, and OM performed lab work for the

1481 PAFTOL samples, and OM curated the PAFTOL data. DA collaborated on all herbarium

1482 work at BO. Sahromi facilitated access and participated in field collections at the Bogor

1483 Botanical Gardens. NJCZ provided overall guidance on Moraceae and facilitated

1484 sequencing at Northwestern University. WJB and FF acquired funding for and supervised

1485 the PAFTOL project. AM performed herbarium sampling at K and supervised the

1486 Moraceae portion of the PAFTOL project. EMG designed the overall study with input from

1487 ALH and NJCZ. ALH supervised the overall study. All authors commented on and

1488 contributed to the manuscript. 
GARDNER ET AL., PHYLOGENOMICS AND GENERIC REVISION OF MOREAE

\section{Acknowledgements}

1492 This work was supported by the United States National Science Foundation (DBI award 1493 number 1711391, and DEB award numbers 0919119 and 1501373); the SYNTHESYS

1494 Project http://www.synthesys.info/ which is financed by European Community Research 1495 Infrastructure Action under the FP7 "Capacities" Program"; the National Parks Board of 1496 Singapore through a Flora of Singapore Fellowship and a Research Fellowship; grants 1497 from the Calleva Foundation and the Sackler Trust to the Plant \& Fungal Trees of Life 1498 Project at the Royal Botanic Gardens, Kew. We thank the Pritzker Laboratory for 1499 Molecular Systematics at the Field Museum of Natural History (K. Feldheim) for access to 1500 laboratory and sequencing facilities; S. Knapp and J. Wajer (BM) for helpful consultation 1501 on nomenclatural issues; W. Clement for helpful comments on the circumscription of the 1502 Olmedieae; the Bogor Botanical Gardens, Singapore Botanic Gardens, and The Morton 1503 Arboretum for access to living collections; and the following herbaria for access to 1504 collections for examination and/or sampling: BM, BKF, BO, CLM, F, IBSC, K, FTBG, L, 1505 MO, NY, SING, SAN, SAR, SNP, and U. Finally, we gratefully acknowledge the careful 1506 work of past scholars of Moraceae, in particular the late C.C. Berg and E.J.H. Corner.

\section{Conflicts of interest}

1509 The authors are unaware of any conflicts of interest affecting this research.

\section{$1511 \quad$ Literature cited}

1513 Bawa, K., \& Crisp, J. 1980. Wind-pollination in the understorey of a rain forest in Costa Rica. J. Ecol., 68: 871-876. Retrieved from http://www.jstor.org/stable/10.2307/2259462

1517 Reproductive biology of tropical lowland rain forest trees. II. Pollination systems. Am. $1518 \quad$ J. Bot., 72: 346-356. https://doi.org/10.2307/2443527 
GARDNER ET AL., PHYLOGENOMICS AND GENERIC REVISION OF MOREAE

1519 Berg, C. C. 1977a. Revisions of African Moraceae (excluding Dorstenia, Ficus, Musanga and Myrianthus). Bull. Du Jard. Bot. Natl. Belgique, 47: 267-407. Retrieved from http://www.jstor.org/stable/10.2307/3667908

Berg, C. C. 1977b. The Castilleae, a tribe of the Moraceae, rename and redefined due tothe exclusion of the type genus Olmedia from the 'Olmedieae'. Acta Bot. Neerl., 26: 7382.

Berg, C. C. 1988. The genera Trophis and Streblus (Moraceae) remodelled. Proc. K. Ned. Akad. van Wet. Ser. C, Biol. Med. Sci., 91: 345-362.

Berg, C. C. 2001. Flora Neotropica Monograph 83: Moreae, Artocarpeae, and Dorstenia (Moraceae), with Introductions to the Family and Ficus and with Additions and Corrections to Flora Neotropica Monograph 7 (Vol. 83).

Berg, C. C. 2005. Flora Malesiana precursor for the treatment of Moraceae 8: other genera than Ficus. Blumea, 50: 535-550. Retrieved from

Berg, C. C., Corner, E. J. H., \& Jarrett, F. M. 2006. Moraceae (genera other than Ficus). Flora Malesiana, Ser. 1, 17: 1-154.

Bolger, A. M., Lohse, M., \& Usadel, B. 2014. Trimmomatic: A flexible trimmer for

Brewer, G. E., Clarkson, J. J., Maurin, O., Zuntini, A. R., Barber, V., Bellot, S., Biggs, Illumina Sequence Data. Bioinformatics, 1-7.

Bureau, E. 1873. Moraceae and Artocarpace. in: A. P. de Candolle, Prodromussystematis

1547 Capella-Gutiérrez, S., Silla-Martínez, J. M., \& Gabaldón, T. 2009. trimAl: A tool for automated alignment trimming in large-scale phylogenetic analyses. Bioinformatics, 
GARDNER ET AL., PHYLOGENOMICS AND GENERIC REVISION OF MOREAE

25: 1972-1973. https://doi.org/10.1093/bioinformatics/btp348

Chen, Z., Yang, T., \& Lu, L. 2016. Tree of life for the genera of Chinese vascular plants. J. Syst. Evol., 54: 273-276. https://doi.org/10.1111/jse.12219

\section{Chung, K. F., Kuo, W. H., Hsu, Y. H., Li, Y. H., Rubite, R. R., \& Xu, W. Bin. 2017.} Molecular recircumscription of Broussonetia (Moraceae) and the identity and taxonomic status of B. kaempferi var. australis. Bot. Stud. https://doi.org/10.1186/s40529-017-0165-y

Clement, W. L., \& Weiblen, G. D. 2009. Morphological Evolution in the Mulberry Family (Moraceae). Syst. Bot., 34: 530-552. https://doi.org/10.1600/036364409789271155

Corner, E. J. H. 1962. The Classification of Moraceae. Gard. Bull., 19: 187-252.

Corner, E. J. H. 1970. New Species of Streblus and Ficus. Blumea, 18: 393-411.

Corner, E. J. H. 1975. The evolution of StrebIus Lour. (Moraceae): with a new species of sect. Bleekrodea. Phytomorphology, 25: 1-12.

Culley, T. M., Weller, S. G., \& Sakai, A. K. 2002. The evolution of wind pollination in angiosperms. Trends Ecol. Evol., 17: 361-369. https://doi.org/10.1016/S01695347(02)02540-5

Datwyler, S. L., \& Weiblen, G. D. 2004. THE ORIGIN OF THE FIG : PHYLOGENETIC NDH F SEQUENCES. Am. J. Bot., 91: 767-777.

Doyle, J., \& Doyle, J. 1987. Genomic plant DNA preparation from fresh tissue-CTAB method. Phytochem. Bull., 19: 11-15.

Engler, G. H. A. 1889. Ulmaceae, Moraceae, and Urticaceae. in: Engler \& Prantl, Die natürlichen Pflanzenfamilien 3(1). Leipzig: W. Engelmann.

Filho, M. D. M. V., Carrijo, T. T., \& Neto, S. R. 2009. Sorocea carautana (Moraceae): A New Species from Southeastern Brazil. Novon A J. Bot. Nomencl. https://doi.org/10.3417/2007143

FitzJohn, R. G. 2012. Diversitree : comparative phylogenetic analyses of diversification in R. Methods Ecol. Evol., 3: 1084-1092. https://doi.org/10.1111/j.2041210X.2012.00234.X

Gardner, E. M. 2017. Dissertation: Evolutionary Transitions: Phylogenomics and 
GARDNER ET AL., PHYLOGENOMICS AND GENERIC REVISION OF MOREAE

Pollination of Artocarpus (Moraceae). https://doi.org/https://doi.org/10.21985/N2CF59

Gardner, E. M., Gagné, R. J., Kendra, P. E., Montgomery, W. S., Raguso, R. A., McNeil, T. T., \& Zerega, N. J. C. 2018. A flower in fruit's clothing: Pollination of jackfruit (artocarpus heterophyllus, moraceae) by a new species of gall midge, clinodiplosis ultracrepidata sp. Nov. (Diptera: Cecidomyiidae). Int. J. Plant Sci., 179: 350-367. https://doi.org/10.1086/697115

Gardner, E. M., Johnson, M. G., Ragone, D., Wickett, N. J., \& Zerega, N. J. C. 2016. Low-Coverage, Whole-Genome Sequencing of Artocarpus camansi (Moraceae) for Phylogenetic Marker Development and Gene Discovery. Appl. Plant Sci., 4: 1600017. https://doi.org/10.3732/apps.1600017

Hale, H., Gardner, E. M. ., Viruel, J., Pokorny, L. ., \& Johnson, M. G. 2020. Strategies for reducing per-sample costs in target capture sequencing for phylogenomics and population genomics in plants. Appl. Plant Sci., in press.

Heibl, C. 2008. PHYLOCH: R language tree plotting tools and interfaces to diverse phylogenetic software packages. http://www.christophheibl.de/Rpackages.html.

Johnson, M. G., Gardner, E. M., Liu, Y., Medina, R., Goffinet, B., Shaw, A. J., Zerega, N. J. C., \& Wickett, N. J. 2016. HybPiper: Extracting Coding Sequence and Introns for Phylogenetics from High-Throughput Sequencing Reads Using Target Enrichment. Appl. Plant Sci., 4: 1600016. https://doi.org/10.3732/apps.1600016

Johnson, M. G., Pokorny, L., Dodsworth, S., Botigué, L. R., Cowan, R. S., Devault, A., Eiserhardt, W. L., Epitawalage, N., Forest, F., Kim, J. T., Leebens-Mack, J. H., Leitch, I. J., Maurin, O., Soltis, D. E., Soltis, P. S., Wong, G. K., Baker, W. J., \& Wickett, N. J. 2019. A Universal Probe Set for Targeted Sequencing of 353 Nuclear Genes from Any Flowering Plant Designed Using k-Medoids Clustering. Syst. Biol., 68: 594-606. https://doi.org/10.1093/sysbio/syy086

Kamneva, O. K., Syring, J., Liston, A., \& Rosenberg, N. A. 2017. Evaluating allopolyploid origins in strawberries (Fragaria) using haplotypes generated from target capture sequencing. BMC Evol. Biol., 17: 1-19. https://doi.org/10.1186/s12862-0171019-7 
GARDNER ET AL., PHYLOGENOMICS AND GENERIC REVISION OF MOREAE

1609 Kates, H. R., Johnson, M. G., Gardner, E. M., Zerega, N. J. C., \& Wickett, N. J. 2018.

1610

1611

1612

1613

1614

1615

1616

1617

1618

1619

1620

1621

1622

1623

1624

1625

1626

1627

1628

1629

1630

1631

1632

1633

1634

1635

1636

1637

1638

Allele phasing has minimal impact on phylogenetic reconstruction from targeted nuclear gene sequences in a case study of Artocarpus. Am. J. Bot. https://doi.org/10.1002/ajb2.1068

Katoh, K., \& Standley, D. M. 2013. MAFFT multiple sequence alignment software version 7: improvements in performance and usability. Mol. Biol. Evol., 30: 772-80. https://doi.org/10.1093/molbev/mst010

Kim, J., \& Sanderson, M. J. 2008. Penalized likelihood phylogenetic inference: Bridging the parsimony-likelihood gap. Syst. Biol. https://doi.org/10.1080/10635150802422274

Kress, W. J., Erickson, D. L., Jones, F. A., Swenson, N. G., Perez, R., Sanjur, O., \& Bermingham, E. 2009. Plant DNA barcodes and a community phylogeny of a tropical forest dynamics plot in Panama. Proc. Natl. Acad. Sci. U. S. A., 106: 18621-18626. https://doi.org/10.1073/pnas.0909820106

Lewis, W. H. 1986. Airborne pollen of the Neotropics:Potential roles in pollination and pollinosis. Grana, 25: 75-83. https://doi.org/10.1080/00173138609429936

Machado, A. F. P., Vianna Filho, M. D. M., Amorim, A. M., \& Romaniuc Neto, S. 2013. A New $<$ I $>$ Sorocea $</ I>$ (Moraceae) From The Atlantic Rainforest, Brazil. Syst. Bot. https://doi.org/10.1600/036364413x670340

Momose, K., Yamaoka, R., \& Inoue, T. 1998. Pollination Biology of the Genus Artocarpus, Moraceae. Tropics, 7: 165-172. https://doi.org/10.3759/tropics.7.165

Nepal, M. 2012. Phylogenetics of Morus (Moraceae) Inferred from ITS and trnL-trnF Sequence Data. Syst. Bot., 37: 442-450. https://doi.org/10.1600/036364412X635485

Paradis, E. 2013. Molecular dating of phylogenies by likelihood methods: A comparison of models and a new information criterion. Mol. Phylogenet. Evol. https://doi.org/10.1016/j.ympev.2013.02.008

Paradis, E., \& Schliep, K. 2019. Ape 5.0: An environment for modern phylogenetics and evolutionary analyses in R. Bioinformatics, 35: 526-528. https://doi.org/10.1093/bioinformatics/bty633

Quinlan, A. R., \& Hall, I. M. 2010. BEDTools: A flexible suite of utilities for comparing genomic features. Bioinformatics, 26: 841-842. 
GARDNER ET AL., PHYLOGENOMICS AND GENERIC REVISION OF MOREAE

https://doi.org/10.1093/bioinformatics/btq033

Rabosky, D. L. 2014. Automatic detection of key innovations, rate shifts, and diversitydependence on phylogenetic trees. PLoS One, 9. https://doi.org/10.1371/journal.pone.0089543

Rabosky, D. L., Donnellan, S. C., Grundler, M., \& Lovette, I. J. 2014a. Analysis and visualization of complex Macroevolutionary dynamics: An example from Australian Scincid lizards. Syst. Biol., 63: 610-627. https://doi.org/10.1093/sysbio/syu025

Rabosky, D. L., Grundler, M., Anderson, C., Title, P., Shi, J. J., Brown, J. W., Huang, H., \& Larson, J. G. 2014b. BAMMtools: An R package for the analysis of evolutionary dynamics on phylogenetic trees. Methods Ecol. Evol., 5: 701-707. https://doi.org/10.1111/2041-210X.12199

Rabosky, D. L., Santini, F., Eastman, J., Smith, S. A., Sidlauskas, B., Chang, J., \& Alfaro, M. E. 2013. Rates of speciation and morphological evolution are correlated across the largest vertebrate radiation. Nat. Commun., 4: 1958. https://doi.org/10.1038/ncomms2958

Revell, L. J. 2012. phytools: An R package for phylogenetic comparative biology (and other things). Methods Ecol. Evol., 3: 217-223. https://doi.org/10.1111/j.2041210X.2011.00169.X

Sakai, S., Kato, M., \& Nagamasu, H. 2000. Artocarpus (Moraceae)-gall midge pollination mutualism mediated by a male-flower parasitic fungus. Am. J. Bot., 87: 440-445. Retrieved from http://www.amjbot.org/content/87/3/440.short

Sanderson, M. J. 2002. Estimating absolute rates of molecular evolution and divergence times: A penalized likelihood approach. Mol. Biol. Evol. https://doi.org/10.1093/oxfordjournals.molbev.a003974

Santos, A. dos, \& Neto, S. R. 2015. Sorocea angustifolia (Moraceae), a New Species of Sorocea from the Atlantic Forest in Brazil . Novon A J. Bot. Nomencl. https://doi.org/10.3417/2013022

Sayyari, E., \& Mirarab, S. 2018. Testing for polytomies in phylogenetic species trees using quartet frequencies. Genes (Basel). https://doi.org/10.3390/genes9030132

Schliep, K. P. 2011. phangorn: Phylogenetic analysis in R. Bioinformatics, 27: 592-593. 
GARDNER ET AL., PHYLOGENOMICS AND GENERIC REVISION OF MOREAE

1669

1670

1671

1672

1673

1674

1675

1676

1677

1678

1679

1680

1681

1682

1683

1684

1685

1686

1687

1688

1689

1690

1691

1692

1693

1694

1695

1696

1697

1698

https://doi.org/10.1093/bioinformatics/btq706

Stamatakis, A. 2014. RAxML version 8: A tool for phylogenetic analysis and postanalysis of large phylogenies. Bioinformatics, 30: 1312-1313. https://doi.org/10.1093/bioinformatics/btu033

Tange, O. 2018. GNU Parallel 2018. Https://Doi.Org/10.5281/Zenodo.1146014. https://doi.org/https://doi.org/10.5281/zenodo.1146014

Team, R. C. 2019. R: A Language and Environment for Statistical Computing. Vienna, Austria.

Villaverde, T., Pokorny, L., Olsson, S., Rincón-Barrado, M., Johnson, M. G., Gardner, E. M., Wickett, N. J., Molero, J., Riina, R., \& Sanmartín, I. 2018. Bridging the micro- and macroevolutionary levels in phylogenomics: Hyb-Seq solves relationships from populations to species and above. New Phytol. https://doi.org/10.1111/nph.15312

Weitemier, K., Straub, S. C. K., Cronn, R. C., Fishbein, M., Schmickl, R., McDonnell, A., \& Liston, A. 2014. Hyb-Seq: Combining Target Enrichment and Genome Skimming for Plant Phylogenomics. Appl. Plant Sci., 2: 1400042. https://doi.org/10.3732/apps.1400042

Wen, D., Yu, Y., Zhu, J., \& Nakhleh, L. 2018. Inferring phylogenetic networks using PhyloNet. Syst. Biol., 67: 735-740. https://doi.org/10.1093/sysbio/syy015

Yu, Y., \& Nakhleh, L. 2015. A maximum pseudo-likelihood approach for phylogenetic networks. BMC Genomics, 16: 1-10. https://doi.org/10.1186/1471-2164-16-S10-S10

Zapata, T. R., \& Arroyo, M. T. K. 1978. Plant Reproductive Ecology of a Secondary Deciduous Tropical Forest in Venezuela. Biotropica, 10: 221. https://doi.org/10.2307/2387907

Zerega, N. J. C., Clement, W. L., Datwyler, S. L., \& Weiblen, G. D. 2005. Biogeography and divergence times in the mulberry family (Moraceae). Mol. Phylogenet. Evol., 37: 402-16. https://doi.org/10.1016/j.ympev.2005.07.004

Zerega, N. J. C., \& Gardner, E. M. 2019. Delimitation of the new tribe Parartocarpeae (Moraceae) is supported by a 333-gene phylogeny and resolves tribal level Moraceae taxonomy. Phytotaxa, 388: 253-265. 
GARDNER ET AL., PHYLOGENOMICS AND GENERIC REVISION OF MOREAE

1699 Zerega, N. J. C., Nur Supardi, M. N., \& Motley, T. J. 2010. Phylogeny and

1700 Recircumscription of Artocarpeae (Moraceae) with a Focus on Artocarpus. Syst. Bot.,

1701 35: 766-782. https://doi.org/10.1600/036364410X539853

1702 Zhang, C., Sayyari, E., \& Mirarab, S. 2017. ASTRAL-III: Increased Scalability and

1703 Impacts of Contracting Low Support Branches BT - Comparative Genomics: 15th

1704 International Workshop, RECOMB CG 2017, Barcelona, Spain, October 4-6, 2017,

1705 Proceedings. in: J. Meidanis \& L. Nakhleh (eds.). Cham: Springer International

1706 Publishing. https://doi.org/10.1007/978-3-319-67979-2_4

1707 Zhang, Q., Onstein, R. E., Little, S. A., \& Sauquet, H. 2019. Estimating divergence

1708 times and ancestral breeding systems in Ficus and Moraceae. Ann. Bot., 123: 191-204.

1709 https://doi.org/10.1093/aob/mcy159

1710

1711

1712 
GARDNER ET AL., PHYLOGENOMICS AND GENERIC REVISION OF MOREAE

\section{Tables}

1714

1715 Table 1. Overview of the taxonomic history of Moreae.

\begin{tabular}{|c|c|c|c|c|}
\hline Engler (1899) & Corner (1962) & Berg (2001) & $\begin{array}{l}\text { Clement \& } \\
\text { Weiblen (2009) }\end{array}$ & Gardner et al. \\
\hline $\begin{array}{l}\text { Morus } \\
\text { Pachytrophe } \\
\text { Paratrophis } \\
\text { Pseudomorus }\end{array}$ & $\begin{array}{l}\text { Ampalis } \\
\text { (Bleekrodea })_{\mathrm{a}} \\
\text { Clarisia } \\
\text { Fatoua } \\
(\text { Maillardia })_{\mathrm{b}} \\
\\
\text { Morus } \\
\text { Pachytrophe } \\
(\text { Paratrophis })_{\mathrm{a}} \\
(\text { Pseudomorus })_{\mathrm{a}} \\
(\text { Pseudostreblus })_{\mathrm{a}} \\
(\text { Sloetia }) \\
(\text { Sloetiopsis })_{\mathrm{a}} \\
\text { Sorocea } \\
\text { Streblus } \\
(\text { Taxotrophis })_{\mathrm{a}} \\
\text { Trophis }\end{array}$ & $\begin{array}{l}(\text { Ampalis })_{\mathrm{a}} \\
\text { Bleekrodea } \\
\text { Broussonetia } \\
\text { Fatoua } \\
\text { Maclura } \\
(\text { Maillardia })_{\mathrm{b}} \\
(\text { Malaisia })_{\mathrm{b}} \\
\text { Milicia } \\
\text { Morus } \\
(\text { Pachytrophe })_{\mathrm{a}} \\
(\text { Paratrophis })_{\mathrm{a}} \\
(\text { Pseudomorus })_{\mathrm{a}} \\
(\text { Pseudostreblus })_{\mathrm{a}} \\
(\text { Sloetia })_{\mathrm{a}} \\
(\text { Sloetiopsis })_{\mathrm{a}} \\
\end{array}$ & $\begin{array}{l} \\
\text { (Maillardia })_{\mathrm{b}} \\
\\
\text { Milicia } \\
\text { Morus } \\
(\text { Pachytrophe })_{\mathrm{a}} \\
\text { (Paratrophis })_{\mathrm{a}} \\
(\text { Pseudomorus })_{\mathrm{a}} \\
(\text { Pseudostreblus })_{\mathrm{a}} \\
\\
\text { (Sloetiopsis })_{\mathrm{a}} \\
\text { Sorocea } \\
\text { Streblus } \\
(\text { Taxotrophis })_{\mathrm{a}} \\
\text { Trophis }\end{array}$ & $\begin{array}{l}\text { Maillardia } \\
\text { Milicia } \\
\text { Morus } \\
\text { (Pachytrophe })_{\mathrm{d}} \\
\text { Paratrophis } \\
\text { (Pseudomorus) } \\
\\
\text { Sorocea } \\
\text { Taxotrophis } \\
\text { Trophis }\end{array}$ \\
\hline
\end{tabular}

a Included in Streblus.

1717 b Included in Trophis.

1718 c Newly separated from Morus.

1719 d Included in Ampalis 
GARDNER ET AL., PHYLOGENOMICS AND GENERIC REVISION OF MOREAE

1720 e Included in Paratrophis.

1721

1722

1723 Table 2. Divergence times (in Ma) estimated using penalized likelihood under correlated

1724 and relaxed models. Nomenclature follows the revisions proposed in this study.

\begin{tabular}{|l|l|l|}
\hline Clade & Correlated & Relaxed \\
\hline Moraceae & 84.7 & 84.7 \\
\hline Parartocarpeae & 75.3 & 74.7 \\
\hline Ficeae & 24 & 34.5 \\
\hline Olmedieae & 36.4 & 43.4 \\
\hline Dorstenieae & 72.5 & 76.9 \\
\hline Maclureae & 44.9 & 52.1 \\
\hline Artocarpeae & 64 & 64 \\
\hline Moreae & 59.1 & 75.4 \\
\hline
\end{tabular}

1725

1726

1727

1728

1729

1730 
GARDNER ET AL., PHYLOGENOMICS AND GENERIC REVISION OF MOREAE

\section{$1731 \quad$ Figures}

1732

1733 Figure 1. Representatives of Moreae: Paratrophis pendulina (=Streblus pendulinus) (a)

1734 infructescences and (b) staminate inflorescences, the latter showing the characteristic sterile

1735 groove; Sorocea racemosa (c) infructescences and (d) staminate inflorescence; Morus nigra

1736 (e) pistillate inflorescences with elaborate stigmas and (f) staminate inflorescences with

1737 stamens that, having been inflexed in bud, are substantially longer than the perianth itself;

1738 and a newly-placed member of Olmedieae (=Castilleae), Streblus asper: (g) infructescences

1739 and (h) discoid-capitate staminate inflorescences with the rudiments of an involucre visible

1740 below the unopened flowers. Photo credits: (a) F. \& Kim Starr, under a CC-BY-3.0-US licence

1741 (https://commons.wikimedia.org/wiki/File:Starr-051029-5102-Streblus_pendulinus-fruit-Auwahi-

1742 Maui_(24481336159).jpg); (b) M. Marathon, CC-BY-SA-4.0

1743 (https://commons.wikimedia.org/wiki/File:Streblus_brunonianus_flowers.jpg); (c)-(d) A. Popovkin, CC-BY-

17442.0 (https://commons.wikimedia.org/wiki/File:Sorocea_racemosa_Gaudich._-_Flickr_-

1745 _Alex_Popovkin,_Bahia,_Brazil_(3).jpg and

1746 https://commons.wikimedia.org/wiki/File:Sorocea_racemosa_Gaudich._-_Flickr_-

1747 _Alex_Popovkin,_Bahia,_Brazil_(9).jpg); (e) E. Gardner; (f) Schurdl, CC-BY-SA-4.0

1748 (https://commons.wikimedia.org/wiki/File:Morus_nigra_100525_02.jpg); (g) D. Valke, CC-BY-SA-2.0

1749 (https://commons.wikimedia.org/wiki/File:Bekar_(Konkani-_बेकर)_(4533519363).jpg); (h) Vinayaraj, CC

1750 BY-SA 4.0 (https://commons.wikimedia.org/wiki/File:Streblus_asper_at_Panamaram_(5).jpg)

1751

1752 


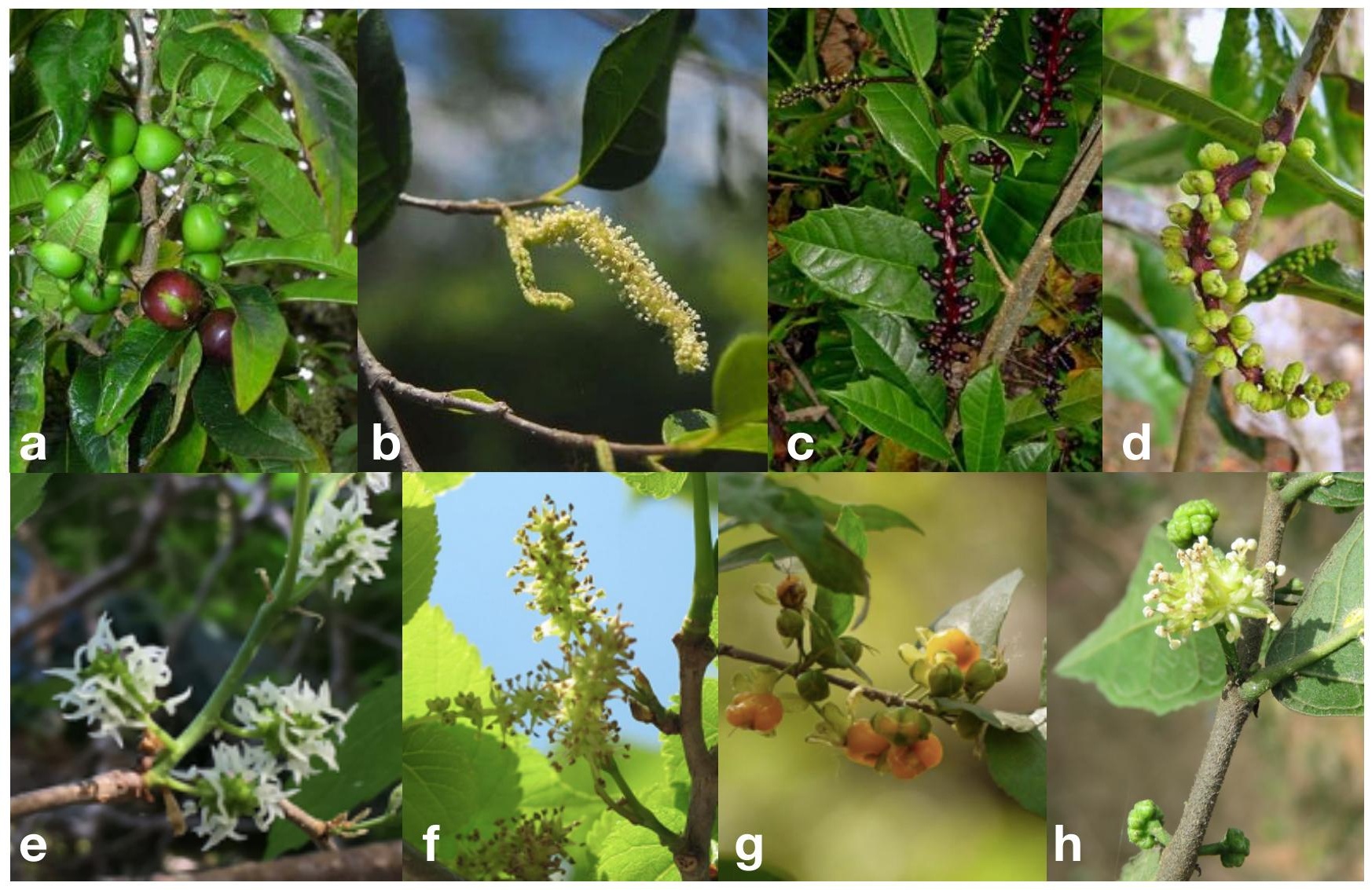


GARDNER ET AL., PHYLOGENOMICS AND GENERIC REVISION OF MOREAE

1768 Figure 2. Phylogenetic trees from the "exon" dataset. Maximum-likelihood based on a

1769 supermatrix of all loci, with bootstrap support and previous nomenclature (left), and a

1770 species tree based on gene trees from all loci with bootstrap/LPP support and revised

1771 nomenclature (right). Discordant branches are colored in red, and tribal classifications are

1772 shaded without (left) and with (right) the revised classifications presented here.

1773

1774 


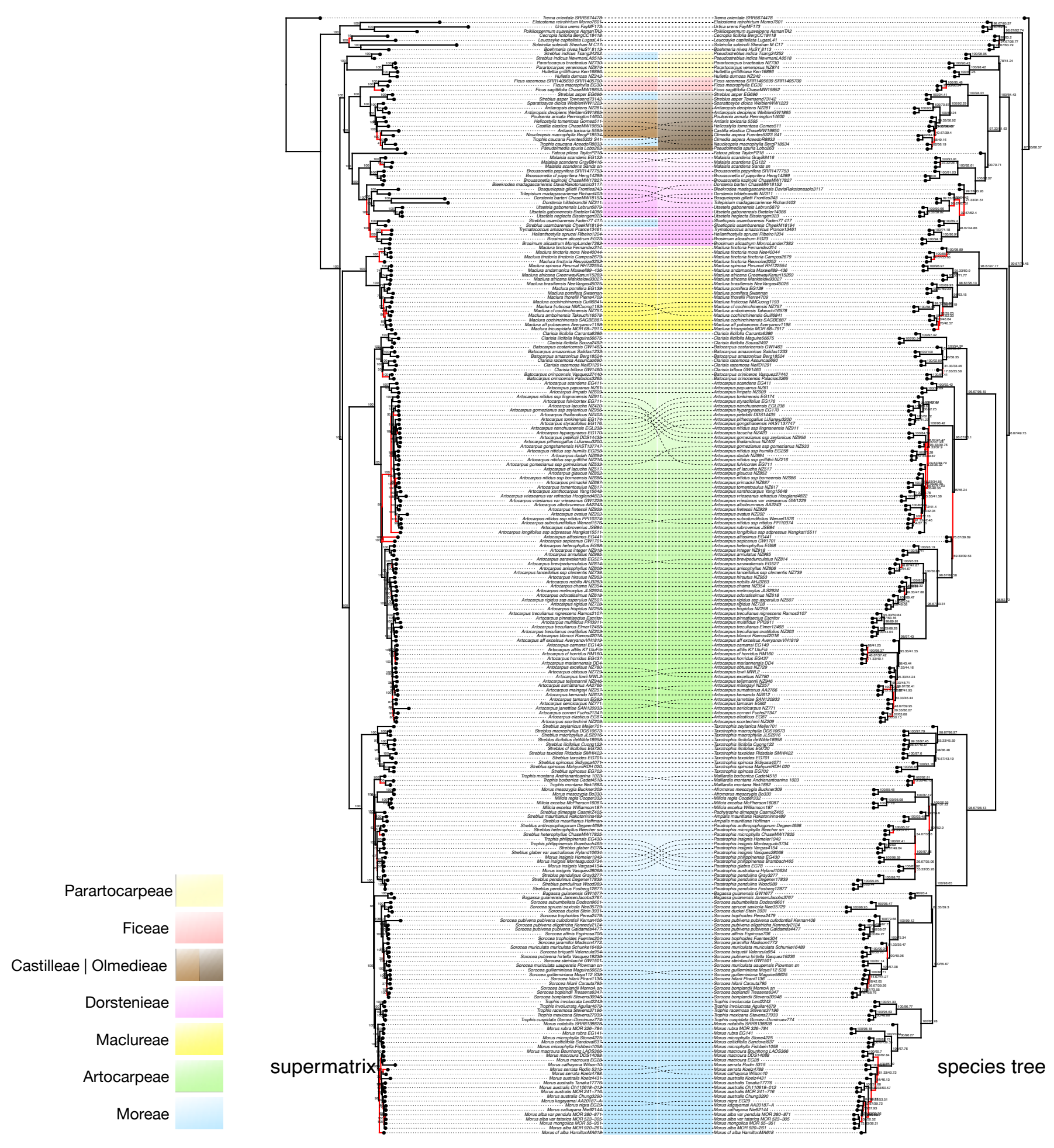




\section{GARDNER ET AL., PHYLOGENOMICS AND GENERIC REVISION OF MOREAE}

1775 Figure 3. Phylogenetic trees of the Moreae clade from the "supercontig" dataset.

1776 Maximum-likelihood based on a supermatrix of all loci, with bootstrap support and

1777 previous nomenclature (left), and a species tree based on gene trees from all loci with

1778 bootstrap/LPP support and revised nomenclature (right). Discordant branches are colored in

1779 red.

1780

1781 


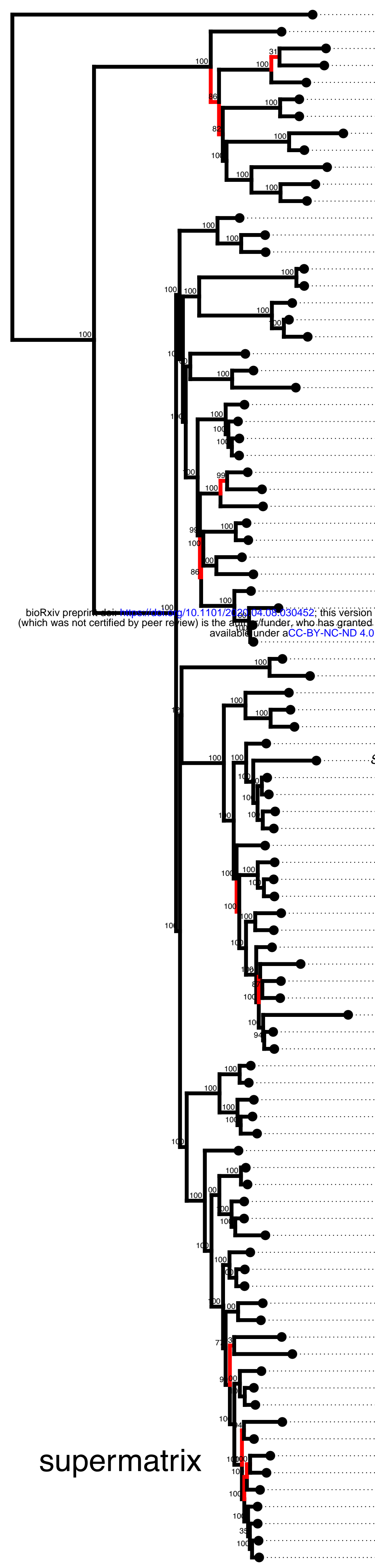

Artocarpus heterophyllus EG98

Milicia excelsa Williamson187

Milicia excelsa Willamson 187

Streblus mauritianus Rakotonirina489-

Streblus mauritianus Hoffman-

Morus insignis Monteagudo3734 -

Morus insignis Vasquez28068

Morus insignis Vasquez28068 Streblus anthropophagorum Degeer4698

Streblus heterophyllus Beecher sin -

Streblus heterophyllus ChaseMW17825

Trs philippinensis Bramb430Streblus glaber EG78

Streblus glaber var australianus Hyland10634 Streblus pendulinus Gray327

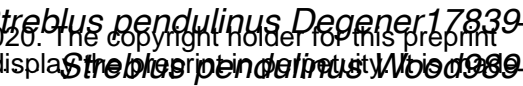

treblus pendulinus Fosberg 12877

Bagassa guianensis Jansen Jacobs3767

Sorocea subumbellata Dodson960

Sorocea sprucei saxicola Nee35729

Sorocea duckei Stein 3931

Sorocea pubivena pubivena cufodontisii Kernan406

Sorocea pubivena pubivena Galdames4477

Sorocea trophoides Fuentes 304

Sorocea affinis Espinosa706

Sorocea jaramilloi Madison4772 -

Sorocea muriculata muriculata Schunke 16489

Sorocea briquetii Valenzula954

Sorocea pubivena hirtella Vasquez19236

Sorocea steinbachii GW1501 .

Sorocea muriculata uaupensis Plowman sn-

Sorocea guile

Sorocea hilarii Pirani1136-

Sorocea hilarii Carauta795

Sorocea bonplandii MonroA sn

Sorocea boplandii Tressens6347

Sorocea bonplandii Stevens30948

Trophis involucrata Lent2243

Trophis involucrata Aguilar4679.

Trophis racemosa Stevens37196 -

Trophis mexicana Stevens27939

Trophis cuspidata Gomez-Dominuez 774

Morus rubra EG141

Morus rubra MOR 326-784

Morus celtidifolia Sandoval637

Morus microphylla Fishbein1058

Morus macroura EG28

Morus macroura Bounhong LAOS366

Morus macroura DDS14088

Morus serrata Rodin 5315

Morus serrata Koelz4788

Morus cathayana Wilson 10

Morus australis Koelz4431

Morus australis Tanaka17776

Morus australis Oh110618-012

Morus australis MOR 241-716

Morus of alba HamiltonMA618 Morus nigra EG29

Morus australis Chung3290

Morus cathayana Nie92144

Morus kagayamai AA20187-A -

Morus alba MOR 920-261

Morus mongolica MOR 55-951

Morus alba var pendula MOR 380-871-
Morus alba var tatarica MOR 523-305

Artocarpus heterophyllus EG98

Taxotrophis macrophylla DDS10673

Taxotrophis ilicifolia deWilde 18958

Taxotrophis ilicifolia Cuong122

Taxotrophis ilicifolia EG720

Taxotrophis zeylanica Maijer70

Taxotrophis taxoides Ridsdale SMHI422

Taxotrophis taxoides EG701

Taxotrophis spinosa Sidiyasa407.1

-Taxotrophis spinosa MahyuniRDH 020

Maillardia montana Andrianantoanina 1023

Maillardia montana Nek1882

Maillardia borbonica Cadet4518.

Afromorus mesozygia Buckner309

Afromorus mesozygia Bo330

Milicia excelsa McPherson 16087

Milicia excelsa Williamson187.

Ampalis dimepate CasmirZ405

-Ampalis mauritiana Hoffman

Paratrophis insignis Homeier1949

Paratrophis insignis Monteagudo3734

Paratrophis insignis Vasquez28068

Paratrophis insignis Vargas4154

Paratrophis anthropophagorum Degeer4698

Paratrophis microphylla Beecher sn

Paratrophis microphylla ChaseMW17825

Paratrophis philippinensis EG430

Paratrophis philippinensis Brambach465

Paratrophis glabra EG78

Paratrophis australiana Hyland10634

-Paratrophis pendulina Gray3277.

Paratrophis pendulina Degener17839

Paratrophis pendulina Wood989

Paratrophis pendulina Fosberg12877.

Bagassa guianensis GW1677

Bagassa guianensis JansenJacobs3767.

Sorocea subumbellata Dodson9601.

Sorocea sprucei saxicola Nee35729

Sorocea duckei Stein 3931

Sorocea trophoides Perea2479

Sorocea pubivena pubivena cufodontisii Kernan 406

Sorocea pubivena pubivena Galdames447.7

Sorocea pubivena oligotricha Kennedy2124

Sorocea trophoides Fuentes304

Sorocea affinis Espinosa706.

Sorocea muricula Madison4772.......

Sorocea briquetii Valenzula954

Sorocea pubivena hirtella Vasquez19236

Sorocea steinbachii GW1501

Sorocea muriculata uaupensis Plowman sn

Sorocea guilleminiana Moya112 S38.

Sorocea guilieminiana Maguire56625

Sorocea hilarii Pirani1 136

Sorocea hilarii Carauta795

Sorocea bonplandii MonroA sn

Sorocea boplandii Tressens6347

Sorocea bonplandii Stevens30948

Trophis involucrata Lent2243

Trophis involucrata Aguilar4679

Trophis racemosa Stevens37196

Trophis mexicana Stevens27939

Trophis cuspidata Gomez-Dominuez774

Morus notabilis SRR8138828

Morus rubra EG141

Morus rubra MOR 326-784.

Morus microphylla Stone4225

Morus celtidifolia Sandoval637. ....

Morus microphylla Fishbein 1058

Morus macroura EG28

Morus macroura Bounhong LAOS366

Morus macroura DDS14088

Morus serrata Rodin 5315

Morus serrata Koelz4788

Morus cathayana Wilson 10

Morus australis Koelz4431

Morus australis Tanaka17776.

Morus australis Oh110618-012

Morus australis MOR 241-716

-Morus cf alba HamiltonMA618

Morus nigra EG29

Morus australis Chung3290.

Morus cathayana Nie92144.

Morus kagayamai AA20187-A

-Morus alba MOR 920-26

Morus mongolica MOR 55-951

Morus alba var pendula MOR 380-871

Morus alba var tatarica MOR 523-305

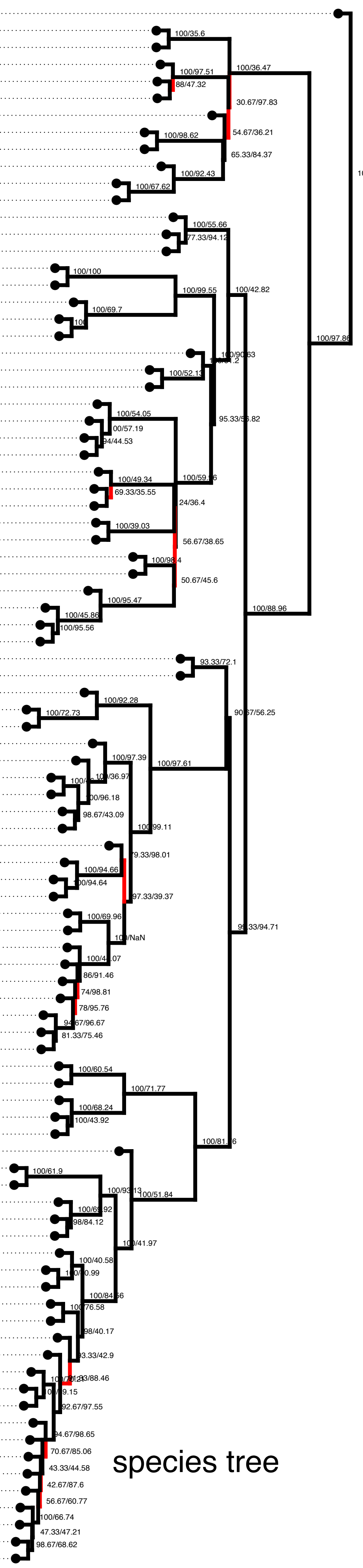


bioRxiv preprint doi: https://doi.org/10.1101/2020.04.08.030452; this version posted August 20,2020. The copyright holder for this preprint (which was not certified by peer review) is the author/funder, who has granted bioRxiv a license to display the preprint in perpetuity. It is made available under aCC-BY-NC-ND 4.0 International license.

\section{GARDNER ET AL., PHYLOGENOMICS AND GENERIC REVISION OF MOREAE}

1782 Figure 4. The best five maximum-pseudo-likelihood phylogenetic networks for the 1783 Paratrophis clade.

1784

1785 

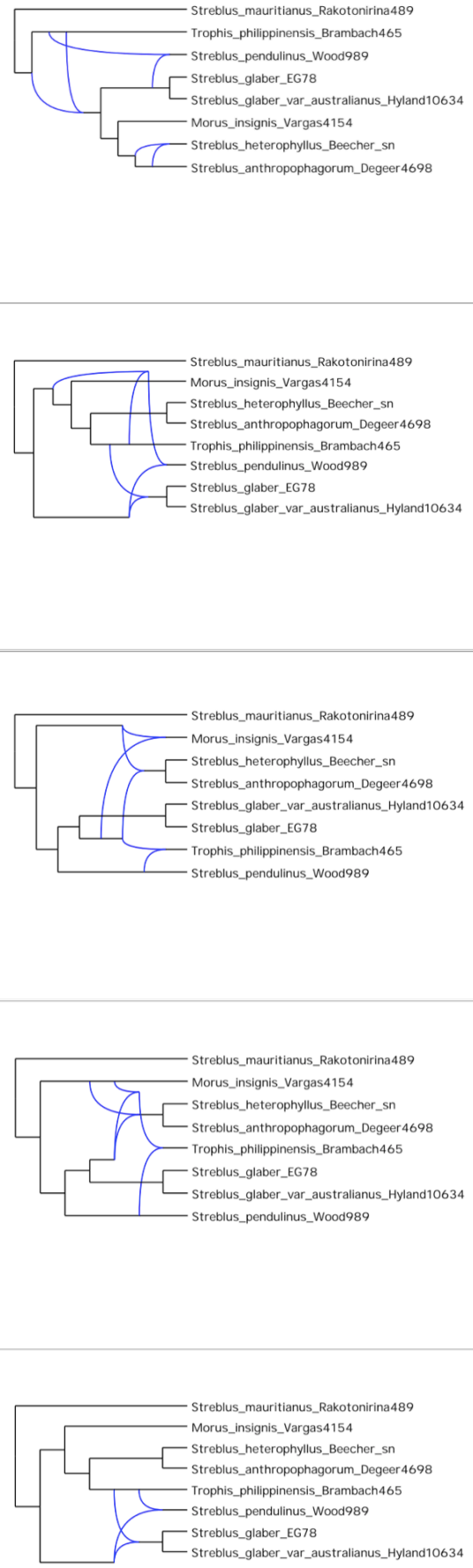
bioRxiv preprint doi: https://doi.org/10.1101/2020.04.08.030452; this version posted August 20,2020. The copyright holder for this preprint (which was not certified by peer review) is the author/funder, who has granted bioRxiv a license to display the preprint in perpetuity. It is made available under aCC-BY-NC-ND 4.0 International license.

GARDNER ET AL., PHYLOGENOMICS AND GENERIC REVISION OF MOREAE

1786 Figure 5. Time-calibrated phylogenetic tree, with revised nomenclature.

1787

1788 


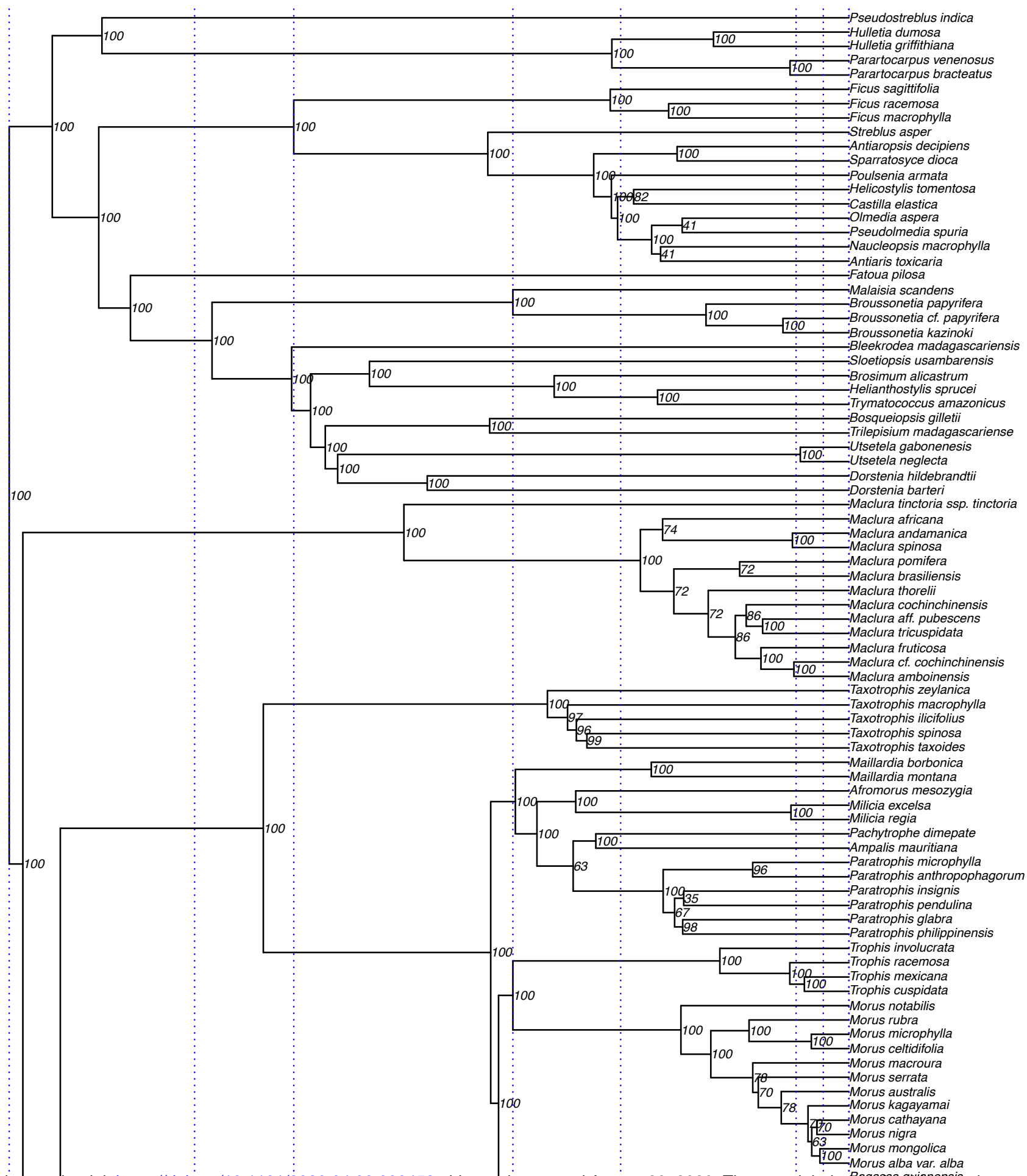

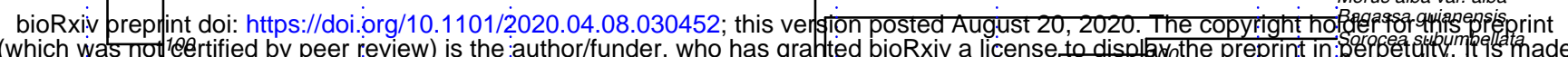

(which was not'leertifiied by peer review) is the author/funder, who has granted bioRxiv a license to displayothe preprint in:
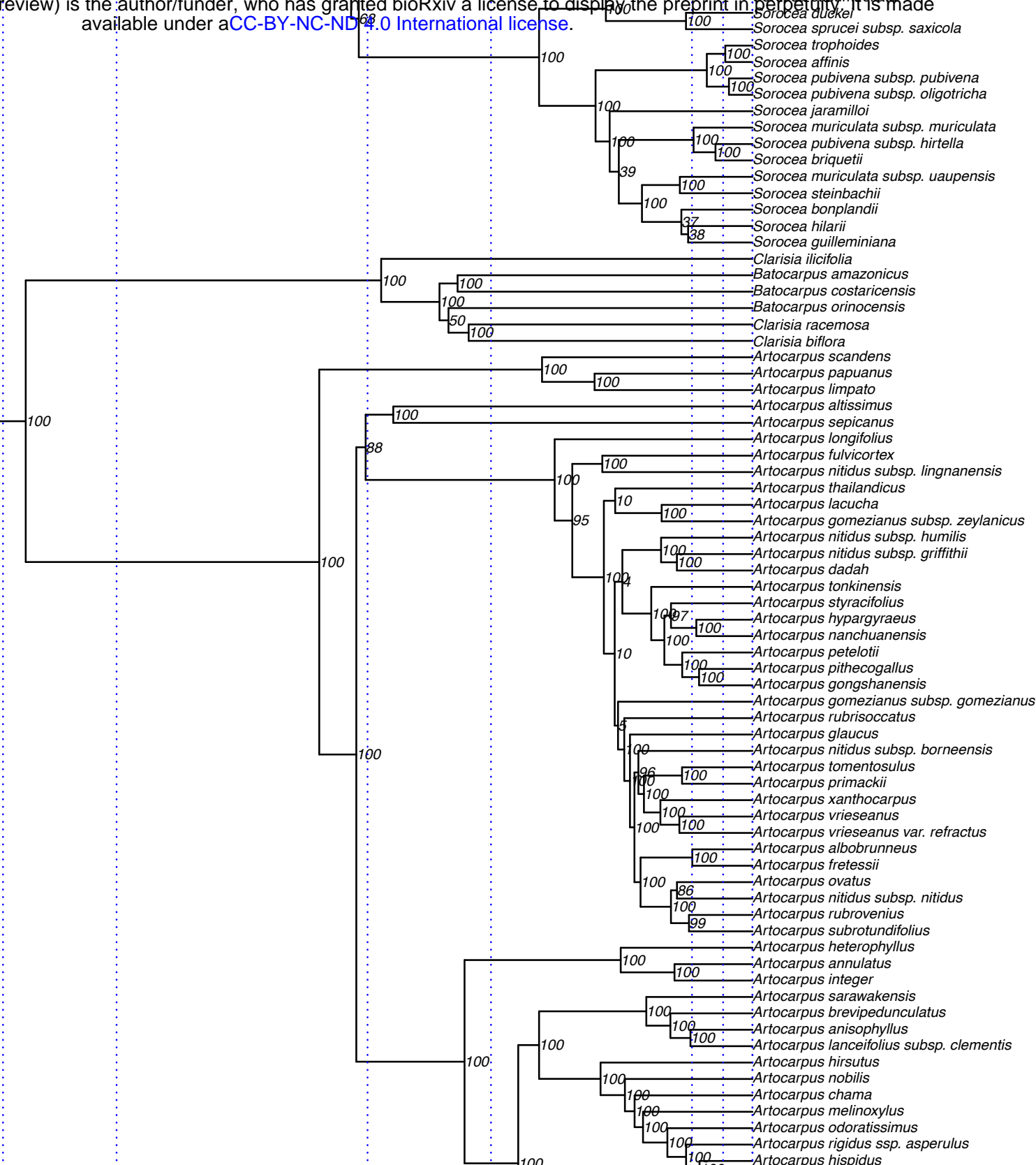

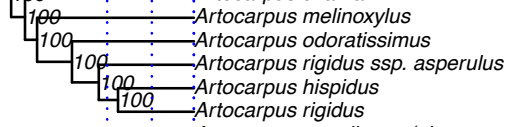

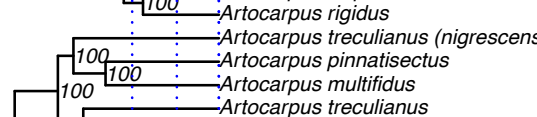

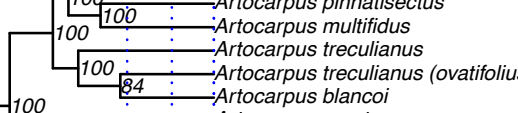

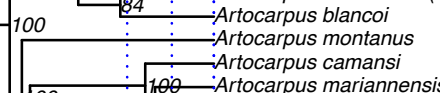

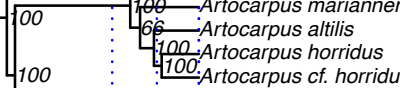

- Artocarpus excelsus

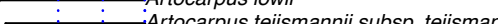

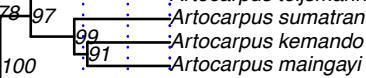

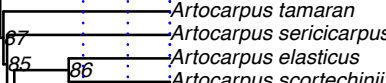

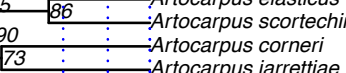


bioRxiv preprint doi: https://doi.org/10.1101/2020.04.08.030452; this version posted August 20,2020. The copyright holder for this preprint (which was not certified by peer review) is the author/funder, who has granted bioRxiv a license to display the preprint in perpetuity. It is made available under aCC-BY-NC-ND 4.0 International license.

GARDNER ET AL., PHYLOGENOMICS AND GENERIC REVISION OF MOREAE

1789 Figure 6. Ancestral reconstruction of stamen position, with revised nomenclature. The

1790 reconstruction was identical under a trait-dependent (BiSSE) or a trait-independent model.

1791 Blue = inflexed in bud; yellow = straight in bud.

1792

1793 


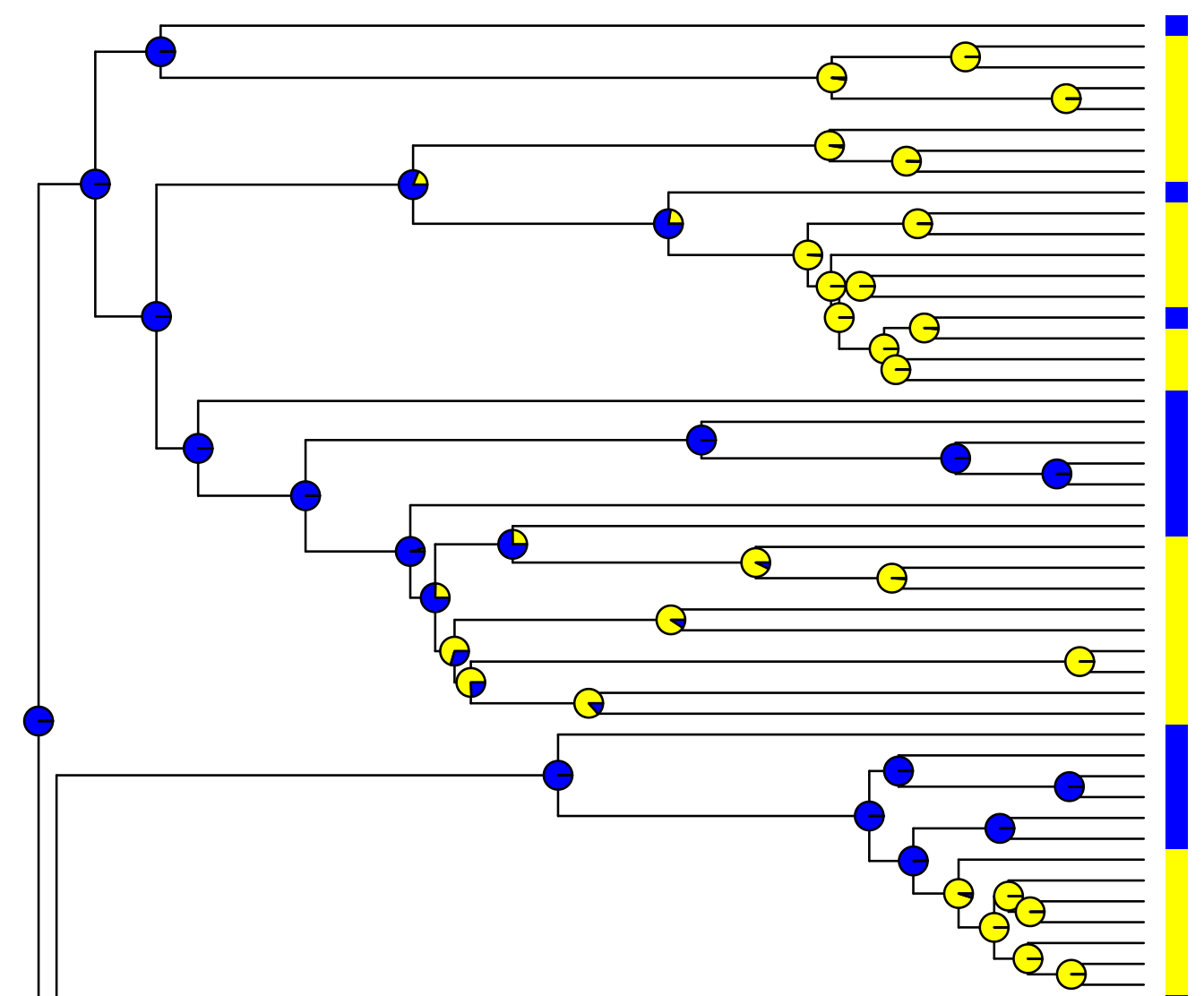

Pseudostreblus indica NewmanLA0518 Hullettia grifititiniana Kerr16886 Parartocarpus bracteatus NZ730 Fis racemosa SRR1405699 SRR1405700 Hitreblus asper EG696
Sting

Sparattosyce dioica WeiblenWW1223 Helicostylis tomentosa Gomes511 Castillie elastica ChaseMWW19850
Olmedia aspera Fuentes5323 S4 Naucleopsis macrophylla Berg 18534

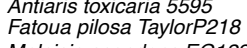

Malaisia scandens EG122
Broussonetia papyrifera SRR1477753

Broussonetia kazinoki ChaseMW17827

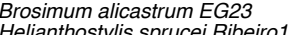

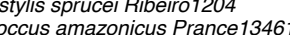

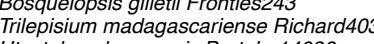

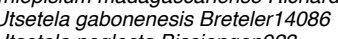

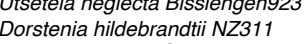
Maclurat tinctoria tinctoria Campos2679 Maclura andamanica MaxwellsgMaculura spinosa Perumal RHT22554

Maclura brassiliensis Neevargas45025

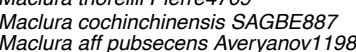
Maclurat tricuspoidata MOR 68-7917 Maclura af cocchinchinensisis NZ757 Maclura amboinensis ake acuchit 6578 Taxotrophis macroohylla DDS 10673 Taxotrophis iliciciolius EGT20 Taxotrophis taxoides EG701

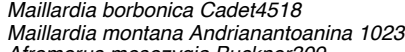

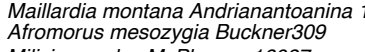
Miliciai excelsa Mc Phersont 16087
Milicia regiac

Pachyrtrophe dimeoate Casmirz 405

Ampalis maurtitiana Hofftman
Paratrophis

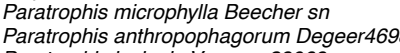

Paratrophis

Paratrophis penduina G Gay 3277
Paratrophis glabra EG78

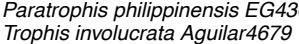

Trophis racemosa Stevens 3719

Trophis mexicana Stevens27939
Trophis cuspidata Gomez-Dominuez774

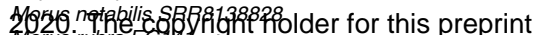

Thars.

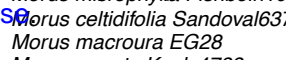

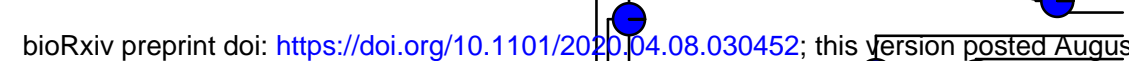

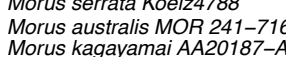

Morrus cathayana Nieg2 144

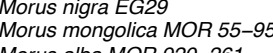

Morus alba MOR $920-261$
Bagassa guianensis GWib77

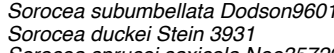

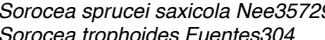

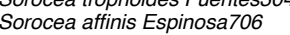

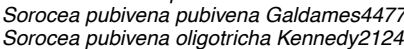

Sorocea iaramilloi Madison 4722

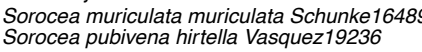

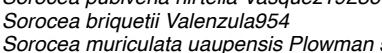

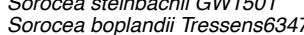

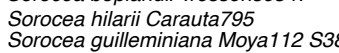

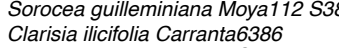

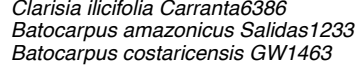

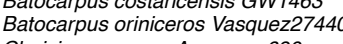

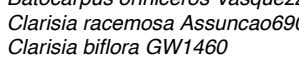

Clarisia bititora GW11460
Artocarrous scandens EG411

Artrocarpus papuanus NZ61
Artocarpus limpato NZ609

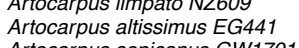

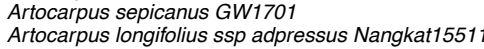

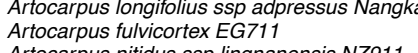

Artocarpus nitidus Ssp lingnanenensis NZ911

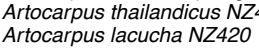

Artocarpus gomezianus ssp zevlanicus N2956 Artocarpus nitidus Ssp humilis EG258
Artocarpus nititus sss orifitithi N2216

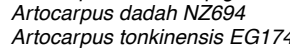

Artocarpus styryacifolius EG EG17

Artocarpus hypargyraeus $E$ EG170
Atrocarpus nanchuanonsis EGLL238

Artocarpus peteletiti D DS14435

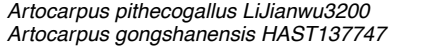

Artocarous gomezianus ssp gomezianus N253

Artocarpus cf flacucha $N 257$
Artioarpus glaucus $N 2852$

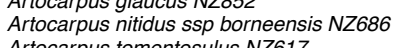

Artocarpus tomentossulus $N Z 6617$
Artocarpus primackii 2687

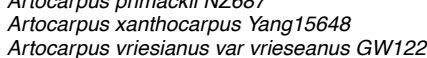

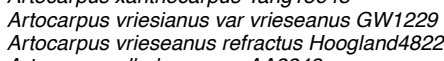

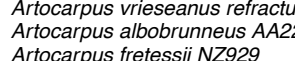

Artocarpus retetessii NZ929

Artocarpus nititus SSP nititus PPI10374

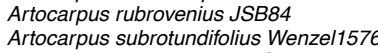

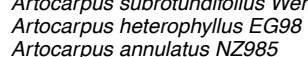

Artocarpus annulatus $N 2985$
Artocarpus integer $N 2918$

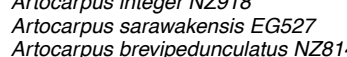

Artrocarpus brevipedunculatus NZ814
Artocarpus anisoonyylus NZ606

Artocarous lanceifolius ss sp clementis NZ739

Artocarpus hirsutus NZ955
Artocarpus nobilis AHIS23

Artocarpus chama NZ354

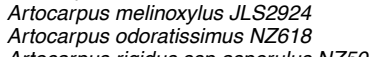

Artocarpus rigidus ssp asperulus NZ507

Artocarpus hispoldus N2258
Artocarpus rigidus NZ720

Artocarpus treculianus nigrescens Ramos2107

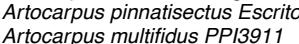

Artrocarpus treceulianus EImer 12468
Artocarus treculianus ovatifilius N2203

Artocarpus treculianus ovatifilius $N 2203$
Artocarpus blancoi

Artocarpus atf excelsus AveryanovVH1819

Artocarpus mariannensis DD4

Artocarpus attilis $K 7$ Ulufriti
Artocarous horridus $E G 437$

Artocarpus of horridus RM160

Artocarpus excelsus $N 7780$
Artocarpus obtusus $N 72729$

Artocarpus obtusus $N$ ZZ72

Artrocarpus teijmmanni N 2946
Artocarpus sumatranus AA2766

Artocarpus sumatranus AA12
Artocaraus k kemanano $N$ N6612

Artocarpus maingayi $N 2257$
Artocarous tamaran EG92

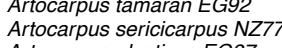

Artocarpus elasticus EGG8
Artocarpus scortechini $N$ N220

Artocarpus correri Euchs21347 
bioRxiv preprint doi: https://doi.org/10.1101/2020.04.08.030452; this version posted August 20,2020. The copyright holder for this preprint (which was not certified by peer review) is the author/funder, who has granted bioRxiv a license to display the preprint in perpetuity. It is made available under aCC-BY-NC-ND 4.0 International license.

\section{GARDNER ET AL., PHYLOGENOMICS AND GENERIC REVISION OF MOREAE}

1794 Figure 7. Revised classification of Moreae on a maximum-likelihood phylogenetic tree of

1795 Moreae based on "supercontig" sequences.

1796

1797 
bioRxiv preprint doi: https://doi.org/10.1101/2020.04.08.030452; this version posted August 20, 2020. The copyright holder for this preprint (which was not certified by peer review) is the author/funder, who has granted bioRxiv a license to display the preprint in perpetuity. It is made available under aCC-BY-NC-ND 4.0 International license.

\section{GARDNER ET AL., PHYLOGENOMICS AND GENERIC REVISION OF MOREAE}

1779 Figure 7. Revised classification of Moreae on a strict consensus tree of all four main

1780 phylogenomic analyses.

1781

1782 
-Taxotrophis zeylanica

Taxotrophis macrophylla

Taxotrophis ilicifolia

Taxotrophis spinosa

-Taxotrophis taxoides

Maillardia montana

Maillardia borbonica

-Afromorus mesozygia

-Milicia excelsa

Milicia regia

Ampalis dimepate

-Ampalis mauritiana

-Paratrophis pendulina

-Paratrophis philippinensis

Paratrophis glabra

Paratrophis insignis

Paratrophis anthropophagorum

Laratrophis microphylla

Trophis involucrata

-Trophis racemosa

Trophis cuspidata

Trophis mexicana

-Morus notabilis

Morus rubra

Morus celtidifolia

Morus microphylla

-Morus macroura

-Morus serrata

- Morus australis

-Morus kagayamai

-Morus cathayana

-Morus nigra

Morus mongolica

Morus alba var. alba

-Bagassa guianensis

-Sorocea subumbellata

Sorocea sprucei subsp. saxicola

Sorocea duckei

$4\left[\begin{array}{l}\text { Sorocea trophoides } \\ \text { Sorocea affinis }\end{array}\right.$

Sorocea pubivena subsp. oligotricha

Sorocea pubivena subsp. pubivena

Sorocea jaramilloi

-Sorocea muriculata subsp. muriculata

Sorocea briquetii

Sorocea pubivena subsp. hirtella

Sorocea muriculata subsp. uaupensis

-Sorocea steinbachii

Sorocea guilleminiana

-Sorocea hilarii

-Sorocea bonplandii

\section{Taxotrophis}

\section{Maillardia Afromorus \\ Milicia \\ Ampalis}

\section{Paratrophis}

\section{Trophis}

\section{Morus}

\section{Bagassa}

\section{Sorocea}

